Business and Economics Research Journal
Volume 9 Number 12018
pp. $25-48$
ISSN: $1309-2448$
www.berjournal.com
DOI Number: $10.20409 /$ berj.2018.92

\title{
Finansal İstikrarsızlığın Ekonomik Büyüme Üzerindeki Etkisi: BRICT Ekonomileri
}

\author{
Filiz Erataş Sönmez ${ }^{\mathrm{a}}$
}

Doğan Uysal ${ }^{b}$

\begin{abstract}
Öz: Bu çalışmanın amacı, finansal istikrarsızlığın ekonomik büyüme üzerindeki etkisini incelemektir. Finansal istikrarsızığın ekonomik büyümeyi olumsuz etkilediği hipotezinden hareketle, öncelikle finansal istikrarsızlığın tanımı yapılmış, ardından kavramsal çerçevenin daha iyi açıklanabilmesi için finansal istikrarsızlığın nedenleri üzerinde durulmuştur. Durağan olmayan dinamik panel veri analizinin kullanıldığı çalışmada, değişkenlerin öncelikle heterojen olup olmadıkları incelenmiş ardından değişkenlere ilişkin yatay kesit bağımılı̆ğı araş̧tıılmıştı. İkinci nesil panel birim kök testlerinden yararlanılan bu modelde, uzun dönem regresyon katsayısı tahmin edilmiş ve finansal istikrarsızlık ile ekonomik büyüme arasındaki nedensellik ilişkinin yönünün belirlenmesi amacıyla panel nedensellik analizinden yararlanılmıştr. Elde edilen ampirik bulgular, finansal istikrarsızlığın ekonomik büyümeyi olumsuz etkilediği hipotezini desteklemektedir.
\end{abstract}

Anahtar Sözcükler: Finansal İstikrarsızlık, Ekonomik Büyüme, Panel Veri Analizi, BRICT

JEL Sınıflandırması: C23, E44, F41, F43

\section{The Impact of Financial Instablity on Economic Growth: BRICT Economies}

\begin{abstract}
The aim of this study is to investigate the impact of financial instability on economic growth. Depart from the hypothesis that financial instability affects economic growth negatively, firstly the definition of instability is made and then focused on the causes of instability to understand a conceptual framework better. In this study, nonstationary dynamic panel data analysis has been used to analyze not only examine the heterogeneity of the variables but also to consider cross-section dependency between cross section units. The second-generation panel unit root tests are utilized in this model, the long-term regression coefficients have been estimated and panel causality analysis is used to determine the direction of the causality relationship between the economic growth and financial instability. The empirical findings of the study support the hypothesis which suggest that financial instability has adverse effects on economic growth.
\end{abstract}

Keywords: Financial Instability, Economic Growth, Panel Data Analysis, BRICT

JEL Classification: C23, E44, F41, F43

\footnotetext{
${ }^{a}$ Res. Asst., PhD., Manisa Celal Bayar University, Faculty of Economics and Administrative Sciences, Department of Economics, Manisa, Turkiye, filiz.eratas@cbu.edu.tr (ORCID ID: 0000-0003-2052-340X)

bProf., PhD., Manisa Celal Bayar University, Faculty of Economics and Administrative Sciences, Department of Economics, Manisa, Turkiye, dogan.uysal@cbu.edu.tr (ORCID ID: 0000-0001-9406-0757)
} 


\section{Giriş}

Finansal küreselleşme ile birlikte ekonomik birimlerin aşırı risk ve sürdürülemez borçlanmaya neden olan davranışları sistemde istikrarsızlığa neden olmaktadır. Ayrıca finansal yeniliklerle birlikte ekonomik birimlerin risk algısı değişmiş finansal istikrarsızlık sorunu daha karmaşık bir hale gelmiştir. Finansal kırılganlığı yüksek bir ekonomide sistemik etkiler de barındırabilecek potansiyel şokların ortaya çıkma riski zamanla artmaktadır. Finansal krizler, niteliklerine bağlı olarak, ekonominin geneli üzerinde olumsuz etkilere neden olmakta ve negatif büyüme rakamları ile karşı karşıya kalınmaktadır.

Ekonomide sürekli istikrar kavramına önem verilmesi nedeniyle ile finansal istikrarsızlık konusunda gerçekçi çözüm önerileri sunmakta yetersiz kalınmaktadır. Çalışmanın çıkış noktası ekonomiler için bir sorun olan finansal istikrarsızlığın saptanması ve ardından çözüm önerilerinin getirilmesidir. Çalışmada hem kavramsal tanımlamalara yer verilmiş hem de finansal istikrarsızlı̆ı̆ özellikle yükselen piyasa ekonomileri için gerçekten bir sorun olup olmadığının ispat için ekonometrik bir model oluşturulmuştur. Amaç, finansal istikrarsızlığın ekonomik büyümeyi negatif etkilediği tezinin bir de ampirik olarak araştırılmasıdır.

Ekonomik yazında finansal istikrar kavramına daha sık rastlanmakta, finansal istikrarsızlık ile ilgili olan sınırı ampirik çalışmaların sonuçları ise ele alınan ülke grupları açısından farklıık göstermektedir. Yapılan bu çalışma ile hem finansal istikrarsızığın kavramsal açıklaması hem de oluşturulan ampirik model ve güncel ekonometrik uygulamalarla ekonomi yazınına katkı yapması beklenmektedir.

Çalışmanın ilk bölümünde, finansal istikrarsızlık sorunu tanımlandıktan sonra, finansal istikrarsızlığa yol açan nedenler üzerinde durulmuştur. İzleyen bölümde finansal istikrarsızlık endeksi oluşturulmuş, ardından analize konu olan çalışmaların özetlendiği yazın taramasına yer verilmiştir.

Çalışmanın son bölümünde finansal istikrarsızlık ve ekonomik büyüme ilişkisinin açıklanması için ekonometrik bir model oluşturulmuştur. Ampirik model kapsamında, durağan olmayan panel veri analizi yöntemlerinden yararlanılmıştır. Finansal istikrarsızlık endeksi ile ekonomik büyüme arasındaki ilişkinin analizine dair uzun dönem regresyon katsayıları ortak ilişkili etkiler modeli ile tahmin edilmiş olup her bir ülkeye ait parametre tahminleri ayrıca yorumlanmıştır. Son olarak, söz konusu iki değişken arası nedensellik analizine yer verilmiş olup nedensellik ilişkisinin yönü belirlenmiştir.

\section{Finansal İstikrarsızlık Kavramı}

Mishkin'e (1999) göre finansal istikrarsızlık, finansal sistemin fonların karlı yatıımlara dönüştürme fonksiyonunu ortadan kaldıran her türlü bilgi dalgalanması olarak tanımlanmaktadır (Mishkin, 1999:7). Minsky ise finansal istikrarsızlığı, gelişmiş finansal kurumların olduğu karmaşık yapılı ekonomilerdeki kişisel çıkar davranışlarının doğal ve ayrılmaz bir parçası olarak tanımlamaktadır (Minsky, 1982:13).

Finansal istikrarsızlık, borçlanma sürecindeki gelişmelere müdahale edilmedikçe kendini tekrarlayan bir sorun olarak ifade edilebilir. Finansal istikrarsızlık, finansal sistemin kendisine yönelik verili bir şoku takip eden krize dayanma yeteneğinin ortadan kaldıran bir unsurdur. Finansal piyasalar, gerekli fonların karlı yatırım firsatlarına sahip özel ya da tüzel kişilere iletilmesini sağlamak gibi önemli bir fonksiyona sahiptir. Eğer finans piyasası bu görevi yerine getiremezse, ekonomik faaliyetlerin etkin bir şekilde devamı sağlanamaz ve ekonomik büyüme zarar görür (Mishkin, 1999:3). Burada karar verilmesi gereken önemli unsurlardan biri de yatırım firsatlarının hangilerinin değerlendirip değerlendirilmeyeceğidir ki bu; asimetrik bilgi teorisine dayanan, ters seçim ve ahlaki tehlike olmak üzere finansal istikrarsızlık için önem taşıyan iki kavramı karşımıza çıkarmaktadır.

Toplumu oluşturan bireyler, ekonomik işleyiş hakkında aynı düzeyde bilgiye sahip değildir. Yaş, eğitim durumu, çevre, kişisel merak ve iletişim teknolojilerini kullanma kapasitesi ekonomik birimlerin bilgi birikimleri arasında farklılık yaratmaktadır. Finans piyasasında ekonomik birimler birbirinden farklı bilgi kümelerine sahiptir ve bu nedenle piyasada dalgalanmalarının olması kaçınılmazdır (Arrow, 2010:289). Ahlaki tehlikede piyasa taraflardan biri diğerinin faaliyetlerini gözetmez (Uysal, 2011:313). Projeleri yüksek riskli yatırımcılar genelde finansman kaynağı için yüksek faiz oranlarına katlanmaktadırlar. Bunun nedeni, projenin hayata geçirilmesini kredinin geri ödenmesinden daha fazla düşünmeleridir. Borç veren durumundaki 
ekonomik birimler, istenmeyen sonuçlarla karşılaşmamak için borç verdikleri projeler hakkında detaylı bilgiye sahip olmalıdır. Akerlof'a (1970) ait "Limonlar Problemi (lemons problem)" analizi ters seçim konusuna verilecek açıklayıcı örneklerden biridir.

Ahlaki tehlike, borçlunun elde ettiği fonu borç verenin bilgisi dahilinde olmadan, kredinin geri ödenmesini engelleyecek her türlü faaliyette kullanması durumunda ortaya çıkan bir unsur olarak tanımlanmaktadır (Mishkin, 2004:174). Borç veren, borçlunun talep ettiği fonu nasıl kullanacağı hakkında tam bir bilgiye sahip değildir. Yatırım projesi hakkında daha fazla bilgiye sahip olan borçlunun, borcu geri ödenmeme riskini artıracak her türlü davranış eğilimi göstermesi mümkündür. Bu davranış genellikle borçlunun, yüksek riskli projeleri tercih etmesi şeklinde ortaya çıkmaktadır.

Finansal piyasalarda da borç veren ve borç alan arasında benzer bir ilişki vardır. Kısıtlı bilgiye sahip olan borç veren, yüksek faiz oranından borç vermeye çekinmektedir. Bunun sebebi yüksek faize katlanacak olan borçluların genellikle geri ödemede yüksek risk taşımalarıdır. Bu doğrultuda, asimetrik bilgiden kaynaklanan ters seçim, finansal piyasanın fon arzı ve fon talebi arasındaki etkin aracılık fonksiyonunu aksattı̆ı için finansal istikrarsızlığı artırmaktadır.

Roubini ve Mihm'e (2011) göre, etkilerinin hala devam ettiği küresel finans kriz ahlaki tehlikeden kaynaklanmıştır. Özellikle finansal hizmetler sektöründe ahlaki risk olgusuna sıkça rastlanmaktadır. Finans piyasasında çalışanlar emeğinin karşılığını alan bir ücretli gibi değil, yatırım bankaları örneğinde olduğu gibi performanslarına göre yıllık prim ödenmektedir. Roubini ve Mihm'in (2011) verdiği örneğe göre, Amerika Birleşik Devletleri'ndeki ilk beş yatırım bankasında (Goldman Sachs, Morgan Stanley, Merill Lynch, Lehman Brothers ve Bear Stearns) çalışanlara ödenen prim 2005 yılında 25 milyar \$, 2006 yılında 36 milyar \$ ve 2007 yııında ise 38 milyar \$ seviyesinde gerçekleşmiştir. Bir yıl içinde yapılan kısa dönemli kar toplamı üzerinden hesaplanan prim sistemi, risk üstlenmeyi ve aşırı borçlanmayı teşvik ederek krizle son bulan finansal istikrarsızlığın artmasına neden olmuştur (Roubini ve Mihm, 2011:68-69). Finansal piyasada meydana gelen ters seçim ve ahlaki tehlike kaynaklı asimetrik bilgi probleminin tanımlanması anlık bir durum değil, sürekli değişken yapısıyla finansal istikrarsızlığı tetikleyip, ekonomiyi etkileyen bir unsur olarak değerlendirilmelidir.

Finansal istikrarsızlığın nedenleri hem Post Keynesyen hem de Yeni Keynesyen bakış açısı ile değerlendirilmektedir. Finansal istikrarsızlığın nedenlerini alt ana başlık altında toplamak mümkündür. Bunlar, finansal sektör bilançolarındaki bozulma, reel sektör bilançolarındaki bozulma, faiz oranlarındaki artış, aşırı borç birikimi, belirsizlikteki arţ̧ ve içgüdüsel tepkidir. Söz konusu nedenler, finansal piyasanın işleyişini aksatarak finansal istikrarsızlığa neden olmaktadır.

Borç veren durumundaki bulunan finansal kurumların bilançolarında meydana gelen olası bir bozulma sonrasında, bilançolarının varlıklar kısmında önemli bir daralma görüleceğinden, piyasadaki varlıklarını sürdürebilmeleri için tercih yapmak zorunda kalacaklardır. Söz konusu kurumlar ya var olan borçlarını azaltacaklar ya da yeni kaynak arayışında bulunacaktır. Örneğin bankaların bilançolarında herhangi bir bozulma meydana geldiğinde, mevcut kabul edilebilir uygun maliyet koşulları altında varlıklarını arttırmaları zorlaşmaktadır. Dolayısıyla bankaların vereceği kredi miktarları azalmakta bu da ekonomik faaliyetleri yavaşlatmaktadır. Banka bilançolarındaki bozulma şiddetliyse kırılganlığın yüksek olduğu bir ekonomide bu durum banka paniklerine yol açacaktır. Beklentilerin olumsuza döndüğü, yatırımcıların finansal piyasaya olan güvenlerinin azaldığı dönemlerde, bankalarda yaşanan yüksek miktarlı mevduat çıkışları banka paniklerini tetiklemekte; aynı zamanda, banka yükümlülüklerinin varlıklarını aşması nedeniyle, banka iflasları meydana gelmektedir (Erarslan ve Timurtaş, 2015:28). Bankacılık sektöründe yaşanan aksaklıklar, para piyasalarında dalgalanmalara neden olduğundan bu durum finansal istikrarsızlığı arttırmaktadır. Finansal piyasada bazı kurumlarda belli sıkıntıların ortaya çıkması, finansal kırılganlığın yüksek olduğu durumlarda piyasanın geneli için güven kaybına neden olmaktadır. Ortaya çıkan bu tip kaygılar mevduat sahiplerinin bankalar hakkındaki düşüncelerini olumsuz yönde değiştirdiğinde, bankacılık sektöründe önemli problemler ortaya çıkmaktadır. 
Finans piyasalarında finans dışı kesimin bilançolarında meydana gelen bozulma özellikle asimetrik bilginin şiddeti açısından önemli bir rol oynamaktadır. Reel sektörde, borçlanan ekonomik birimlerin bilançolarında yaygın bir şekilde bozulma yaşanıyorsa, ters seçim ve ahlaki tehlike yoluyla beslenen finansal istikrarsızlık finansal piyasaları olumsuz yönde etkileyecektir (Mishkin, 1999:11).

Bankalar yaşanan asimetrik enformasyon sorunu karşısında kredilerin geri ödenmeme riskini almak istemedikleri için çoğu zaman kredi tayınlamasını tercih etmektedir (Stiglitz ve Weiss, 1981:393). Asimetrik bilgi teorisi kapsamında, bazı yüksek faiz oranı ödemeye razı borç talep edenler kredi tayınlaması nedeniyle reddedilmektedirler. Bunun nedeni, yüksek faiz oranına razı borçluların genellikle yüksek riskli yatırımlara sahip olmalarıdır. Yüksek faiz oranlarını gören ihtiyatlı yatıımcılar, söz konusu faiz oranından borçlanmayı akılcı bulmazken, en yüksek riskin en çok kazanç sağlayacağını düşünen yatırımcılar mevcut yüksek faiz oranından borçlanmayı tercih edecektir (Mishkin, 1998:9). Bu durum finansal istikrarsızlığı hızlandırdığı gibi, fon talep edenlerden bazılarının piyasadan çekilmesine ve dolayısıyla kaynak aktarımının da azalmasına neden olmaktadır.

Borç birikimi teorisine göre, aşırı borç refah döneminde farkına varılmayan büyük bir sistemik risk oluşturur. Örneğin herhangi bir ülkenin aldığı dış borç, söz konusu ülke için gerçek olandan daha fazla bir büyüme sağlamış gibi gösterebilmektedir. Özel kesim borçlarındaki artı̧̧ menkul ve gayrimenkullerin artan talebine bağlı olarak fiyatlarını artırır ve bu durum söz konusu aktiflere sahip kurumların daha karlı algılanmasına neden olmaktadır. Borç birikimi, uzun dönemde sürdürülebilir düzeylerin çok üzerine çıktğı için, ekonomiyi kırılgan hale getirir. Özellikle borçlar kısa vadeli ise, finansal istikrarsızlık artacaktır. Borca dayalı canlanma dönemleri, hükümetlerin ekonomi politikaları, finansal kurumların karlılığı ve yaşam standartlarının algılanmasına dair yanılgılar yaratır (Kemal, 2001:263).

Finansal piyasalardaki belirsizlik artışı ekonomik birimlerin beklentilerini olumsuz yönde etkilemektedir. Piyasada belirsizlik hakim olduğunda, borç verenler için nereye kaynak aktaracaklarının kararı ve risklerinin değerlendirilmesi güçleştirmektedir. Belirsizliğin arttğı bir finansal sistemde, ters seçim ve ahlaki tehlike artacağı için, kaynak bulmakta güçlük çeken proje sahipleri nedeniyle yatırımlar azalacak bu da ekonomik faaliyetlerin durgunlaşmasına neden olacaktır.

İçgüdüsel tepki (animal spirits), insan psikolojisinin ekonomik kararları nasıl etkilediğini ve küresel ekonomi için neden önemli olduğunu açıklayan bir kavramdır. Öncelikle Keynes'in bahsettiği söz konusu kavram, Akerlof ve Shiller (2009) tarafindan yeniden yorumlanmıştır. Ekonomilerin nasıl işlediğini ve ekonomik olayların nasıl yönetileceğini anlamak için insanların fikir ve duygularına hayat veren düşünce örüntüleri ile içgüdüsel tepkilerinin de önemsenmesi gerekmektedir. Akerlof ve Shiller ekonomi biliminde insan davranışlarının da incelenmesi gerektiğini ancak bu yolla krizlerin önüne geçilebileceğini vurgulamaktadır ve özellikle son yaşanan küresel finansal krizin insan davranışlarını dikkate almayan ekonomik model ve politikalar nedeniyle ortaya çıktı̆ı vurgulamaktadırlar. Yüksek riskin farkına varılamaması, ahlaki çöküşün dikkate alınmadan kazanç dürtüsü ile sürekli artan türev ürünler işlem hacmi insanın içgüdüsel tepkilerinin bir sonucudur ve geliyorum diyen küresel bir kriz önlenememiştir. Akerlof ve Shiller durumu şöyle özetlemektedir: "Önemli ekonomik olayların nedenlerinin yapıları gereği büyük ölçüde zihinsel olduğu gerçeği ile yüzleşmedikçe olanlar asla gerçekten anlaşılamayacaktır" (Akerlof ve Shiller, 2010:22).

\section{Finansal Küreselleşme ve Finansal İstikrarsızlık}

Finansal istikrarsızlık ve aşırı borçlanma, kapitalizmin 21. yüzyılın başından itibaren kendi kendini üretebildiği iki temel olgudur. Bunların işleyiş biçimleri, karşımıza periyodik krizleri çıkarmaktadır (Yeldan, 2009:28).

Gelişmiş ülkelerde başlayan ve 1980 'li yıllarla birlikte GOÜ'leri de kapsayacak biçimde yaygınlaşan finansal serbestleşme politikaları ile öncelikle ulusal finansal sistemdeki devamında da sermaye akımları üzerindeki kısıtlamalar ortadan kaldırılmıştır. Sermaye akımları üzerindeki kısıtlamaların ortadan kaldırılması teknolojik gelişmelerle birleşince, uluslararası finansal sistemde mobilitesi artan finansal akımlar artarak çoğalmış ve ciddi oranda yüksek miktarlara ulaşmıştr. Yaşanan gelişmeler ışığında uluslararası sermaye 
akımları esas fonksiyonundan uzaklaşarak daha farklı bir hale dönüşmüştür. Gelişmiş ülkelerden farklı olarak GOÜ'ler uluslararası sermaye hareketlerinden büyüyen hacminin yanı sıra vadesinin kısalmasından ve daha spekülatif bir şekil almasından da etkilenmişlerdir. Ayrıca, kamu borçlanmasından ziyade özel sektör borçlanmasını finanse eden uluslararası sermaye akımları GOÜ'ler açısından ciddi riskleri de beraberinde getirmiştir (Turan, 2011:1).

Telekomünikasyon teknolojisindeki gelişmeler doğrultusunda ortaya çıkan maliyet düşüşleri ulusal sınırlar dışında yatırım yapmayı daha kolay hale getirmiştir. Ayrıca yirmi dört saat işlem yapılabilen hisse senedi, bono ve tahvil piyasalarında yatırımın kolaylaşması nedeniyle, yatırımcılar söz konusu piyasaları giderek daha çok tercih eder hale gelmişlerdir. Önceden yatırımcılar sadece bulundukları ülkede yatırım yapabilirken, şimdi dünyanın herhangi bir yerindeki piyasaya kolayca ulaşabilmektedirler. Ulusal piyasaların uluslararası finansal piyasa ile giderek bütünleşmesi sonucunda herhangi bir ülke meydana gelen ekonomik şok diğer ülke piyasalarını da kısa zamanda etkilemektedir ve dolayısıyla bu özellik piyasaların daha kırılgan hale gelmesine neden olmaktadır. Bu doğrultuda, finansal piyasaların birbirileri ile giderek artan etkileşimi sonucunda, ulusal piyasalar üzerinde yerel değişkenler kadar, uluslararası değişkenlerin de etkili olduğu ifade edilebilir (Sever vd., 2010:50).

Finansal yeniliklerin ulusal piyasalar üzerinde iki farklı etkisi bulunmaktadır. Bunlardan ilki, finansal hizmetlerin gelişmesiyle birlikte işlem maliyetlerinin azalarak işlem bazında etkinliğin artmasına katkıda bulunmasıdır. İkinci önemli etki ise, ulusal ve uluslararası piyasaları daha bütünleştirici olması yönünde bir ivme kazandırmasıdır. Finansal araçlardaki artı̧, ekonomik birimler tarafindan tutulan finansal varlık kompozisyonunda çeşitli değişiklikler yaratmaktadır. Tüm bunların ışı̆ında, finansal küreselleşme ile birlikte, finansal yeniliklerdeki hızlı artışın para arzı, para talebi ve parasal aktarım mekanizmasında değişiklikler meydana getirdiği söylenebilmektedir (Turan, 2011:8).

Finansal küreselleşmenin önemli bir etkisi de reel getirilerin önemini yitirerek spekülatif güdülerin üretken yatııılara baskın çıkmasıdır. İstikrarsız bir finansal sistem artan kırılganlık nedeniyle krizlere yatkın hale gelmektedir ve söz konusu krizler daha sonra uluslararası bir hal kazanarak, ulusal ekonomi politikalarının da denetimini güçleşmektedir (Durusoy, 2009:373).

\section{Finansal İstikrarsızlığın Nicel Olarak Ölçülmesi: Finansal İstikrarsızlık Endeksi}

Finansal istikrarsızlıkla ilgili önemli sorunlardan biri de istikrarsızlık olgusunun niteliksel ve niceliksel bir ölçütünün oluşturulup oluşturulamayacă̆ıdır. Finansal değişkenlerde meydana gelen değişimlerin hangilerinin nasıl ve ne ölçüde istikrarsızık hakkında bilgi sağladığını ayırt etmek gerekmektedir. Aynı şekilde, kimi makroekonomik değişkenler de finansal istikrarsızlıkla ilişkilendirildikleri ölçüde istikrarsızlığa karşı gerçekçi bir öngörü sağlayabilmektedir (Bilgin, 2007:64).

Finansal sistemin istikrarına ilişkin bu yaklaşım çerçevesinde, finansal sistemdeki risk ve kırılganlık durumu saptanmaktadır. Finansal sistemin mevcut sağlamlığı ve istikrarının analizinde kullanılan temel göstergeler, finansal sistemin işleyişine yönelik finansal ve makroekonomik değişkenlerden oluşmaktadır.

Ekonominin içinde bulunduğu finansal sistemin işleyişini etkilemesi ve finansal kurumların makroekonomik bazı gelişmelerden etkilenmesi nedeniyle, makroekonomik gelişmelere yönelik göstergelerin istikrarsızık analizinde kullanılması önemli bir unsur olarak karşımıza çıkmaktadır. Milli gelirin azalması, cari işlemler açığııın artması, dış borçlanmanın artması, enflasyon oranının yükselmesi, faiz oranı ve döviz kurundaki oynaklık, kullanılan kredilerdeki artı̧ gibi değişmeler finansal istikrarsızlık sorununu beslemektedir (Enowbi ve Kupukile, 2012:8).

Finansal istikrarsızlık ya da diğer adıyla finansal stres endeksinin bir avantajı da dinamik olarak finansal istikrar seviyesinin belirlenmesidir (Albulescu, 2012:89). Finansal istikrar özellikle son uluslararası finansal krizden sonra iktisat yazınında oldukça önem kazanmıştır. Özellikle merkez bankalarının söz konusu kriz sonrasında fiyat istikrarı hedefinin yanında finansal istikrarı temel hedefleri arasına koyduğu görülmektedir. Bu amaca yönelik, merkez bankası bünyesinde ya da çeşitli kurumlarda finansal istikrar 
komitelerinin kurulduğu ya da ilgili idari bölümlerin finansal istikrar raporları yayımladığı bilinmektedir (TCMB 2016:1; IMF 2016:1).

Ekonomi yazınında finansal istikrarsızlık endeksi, finansal stres endeksi ya da finansal istikrar endeksi ismiyle yer almaktadır. Bu çalışmalara Illıng ve Liu $(2003,2006)$, Nelson ve Perli $(2005)$, Gerls ve Hemanek (2006), Cihak (2007), Roubah (2007) ve Albulescu (2010,2012), Vermeulen vd. (2015), Karanovic ve Karanovic (2015) örnek olarak gösterilebilir. İktisat yazınında bu endeksi konu edinen pek çok çalışma yer almaktadır. Kullanılan isim farklı olmakla birlikte endeksin içeriği ve tanımlamalar çoğu zaman aynıdır. Finansal istikrarsızlık endeksine ilişkin tek ülke analizlerinin Illing ve Liu (2006), Hakkia ve Keaton (2009), Davig ve Hakkio (2010), Hatzius vd. (2010), Sinenko vd. (2013) Roye (2014) yanı sıra çoklu ülke analizleri Homfeldt vd. (2009), Albulescu (2010), Grimaldi (2010), Afonso vd. (2011), Cardarelli vd. (2011), Sligenberg ve Hoan (2011), Hollo vd. (2012), Albulescu (2012), Çevik vd. (2013), İslami ve Kurz-Kim (2013), Jakubik ve Slacik (2013), Vermeulen vd. (2015), Ahmed vd. (2015) de bulunmaktadır.

Finansal istikrarsızlık endeksinin kaynakları genel olarak, erken uyarı sistemleri değişkenleri, makro stres testlerinde yer alan değişkenler ve finansal istikrar tanımlaması altında kullanılan değişkenlerden oluşmaktadır (Jakubik ve Slacik, 2013:102). IMF'nin 2008 ve Avupa Merkez Bankası'nın (Europe Central BankECB) 2010 yılında finansal stres endeksini kullanmasından sonra finansal istikrarsızlık endeksinin popülerliği artmıştır. Söz konusu finansal stres endeksi finansal istikrarsızlık göstergelerinin bileşiminden meydana gelmektedir.

Finansal istikrarsızlık endeksi oluşturulurken endekslemede hangi yöntem seçilirse seçilsin belli başlı birkaç aşama izlenmektedir. Öncelikle finansal istikrarsızlığı etkileyen ve gösterge olarak kullanılabilecek değişkenler seçilmektedir. Söz konusu değişkenler genellikle finansal sistemin gelişimini, bankacılık sektörünün performansını veya makroekonomik durumu öne çıkaran değişkenlerdir. Ikinci olarak, değişkenler endeks içerisinde birim olarak uyumlaştrılımaktadır. Ardından değişkenler normalleştirilmekte, standartlaştırımaktadır. Ardından gerekli olan durumlarda değişkenler ağırlıklandırımaktadır (Albulescu:2011: 31-32).

Son zamanlarda yapılan pek çok çalışmada finansal piyasalar ve ekonomi arasındaki doğrusal olmayan ilişkinin varlığına vurgu yapılmaktadır (Davig ve Hakkio, 2010; Liu vd., 2011, Hubrich ve Tetlow, 2012; Mittnik ve Semmler, 2013; Brunnerneimer ve Sannkiov, 2014; Ubilava, 2014). Hubrich ve Tetlow (2012)'ye göre bunun temel nedeni finansal dalgalanmalar söz konusu olduğunda ekonomik birimlerin farklı davranış biçimlerine meyilli olması ve rasyonel davranmasıdır. Bu çalışmada finans piyasası ve ekonomi arasında dinamik ilişkinin doğrusal olmayan yapısı dikkate alınarak Temel Bileşenler Analizine-TBA (Principal Component Analysis-PCA) yer verilmiştir. TBA'nın endeksleme yöntemi olarak kullanıldığı çalışmalara örnek olarak Illing ve Liu (2003,2006), Hakkio ve Keaton (2009), Kliesen vd. (2012), Hollo vd. (2012) ve Roye ve Björn (2014) çalışmaları gösterilebilmektedir.

Bu çalışmada finansal istikrarsızlık endeksi elde edilirken; Creel vd.'nin ve (2014), kullandığı TBA yönteminden faydalanılmıştır. TBA, genel faktör analizinin özel bir şekli olup, çok değişkenli analiz yöntemlerinin en eski ve en çok kullanılanlarından biridir .

TBA, aralarında korelasyon bulunan $p$ sayıda değişkenin açıkladığı yapıyı, aralarında korelasyon olmayan ve orijinal değişken sayısı $p^{\prime}$ den daha az olan $k$ sayıda değişkenin doğrusal bileşeni ifade etmektir. TBA'nın esas amacı birden fazla değişkenli bir veri setinde ilgili bilgi yapısını koruyarak boyut sayısını azaltmaktır. TBA orijinal değişkenlerin doğrusal bir fonksiyonu olup, birbirinden bağımsız ve sıralı değişkenlerin yeni bir veri setine dönüştürülmesidir. Söz konusu analizde bileşenler birbirinden bağımsız oldukları için çoklu doğrusal bağlant problemi veya değişkenler arası bağımlılık sorunu mevcut değildir (Pradhan, 2013:311).

TBA analizine dahil edilen ve finansal istikrarsızlık endeksini (FII) oluşturan değişkenler aşağıdaki tabloda belirtilmiştir. Finansal istikrarsızlık endeksi Albulescu (2011) çalışmasından yola çıkılarak makro finansal verilerinden derlenerek meydana getirilmiştir. 
Tablo 1. Finansal İstikrarsızlık Göstergeleri

\begin{tabular}{ll}
\multicolumn{1}{c}{ Değişken } & Veri Kaynağı \\
\hline Yurtiçi krediler/GSYiH (\%) & World Bank-GFD \\
Özkaynak karlılığı (Return on Equity-ROE) (\%) & World Bank-GFD \\
Aktif Karlılığı (Return on Assets-ROA) (\%) & World Bank-GFD \\
Sorunlu Krediler/Toplam Krediler (\%) & World Bank-GFD \\
Net Faiz Marjı (\%) & World Bank-GFD \\
Cari Açı/GSYiH (\%) & IMF-WEO \\
Enflasyon Oranı (\%) & IMF-WEO \\
\hline
\end{tabular}

Not: FIl endeksini oluşturan veriler World Bank Global Financial Development ve IMF World Economic Outlook veri tabanlarından elde edilmiştir.

Çalışmanın ampirik modeline yön veren sınırlı sayıdaki çalışmalar başlıca iki gruba ayrılmaktadır. Bunlardan ilki finansal istikrarsızlığın ekonomik aktivite üzerine yapılan analizlerden oluşurken, diğer grup çalışmalar ise finansal istikrarsızık ile ekonomik büyüme ilişkisini incelemektedir. Bu çalışmada çoklu ülke analizine ve ülkeler arası karşılaştırmalara olanak tanıyan panel veri analizi tercih edilmiştir. Finansal istikrarsızlığın zaman içerisinde ekonomik büyümeyi nasıl ve hangi yönde etkilediğinin BRICT ülkeleri için analiz edilmesi amaçlanmaktadır.

Ampirik modele yön veren, panel veri analizlerinin yer aldığı çalışmalar incelenmiştir. Loayza ve Ranciere (2006) çalışmalarında 1960-2000 dönemi için 75 ülkenin yıllık verileriyle ekonometrik bir model oluşturmuşlardır. Generalized Method of Moment (GMM) yöntemiyle tahmin edilen model bulgularına göre, söz konusu ülkeler için finansal gelişmenin ekonomik büyümeyi arttırdığını fakat finansal kırılganlığın ekonomik büyümeye zarar verdiği sonucuna ulaşmışlardır.

Eggoh (2008) 1960-2004 döneminde 71 ülkeyi incelediği çalışmasında, panel veri analizi kapsamında GMM yönteminden yararlanmışttr. Elde ettiği ampirik sonuçlara göre, uzun ve kısa dönemde finansal gelişme ile ekonomik büyüme arasında pozitif bir ilişki vardır. Ayrıca uzun dönemde finansal istikrarsızık ve ekonomik büyüme arasında anlamlı bir ilişki bulunmazken, kısa dönemde finansal istikrarsızlık ekonomik büyümeyi olumsuz yönde etkilemektedir.

Enowbi ve Kupukile (2012) çalışmasında finansal istikrarsızlık, finansal dışa açıklık ve ekonomik büyüme ilişkisini 1985-2010 döneminde 41 Afrika ülkesi için incelemişlerdir. Dinamik panel veri analizine yer verdikleri çalışmalarında GMM yöntemiyle tahminledikleri ekonometrik model sonucunda finansal dışa açıklı̆ın finansal gelişmeyi arttırdığını; fakat finansal istikrarsızlığın ekonomik büyümeyi olumsuz yönde etkilediği sonucuna ulaşmışlardır.

Ubiliva (2014) çalışmasında finansal istikrarsızlık ve ekonomik aktivite arasındaki ilişkiyi incelemiştir. STAR ve VSTAR yöntemiyle tahmin edilen çalışmadan elde edilen bulgulara göre finansal istikrarsızlığın ekonomik büyümeyi azalttğı sonucuna varmıştr.

Creel vd. (2014) çalışmasında finansal istikrarsızlığı TBA ile elde ettikleri finansal istikrarsızlık endeksi ile ifade etmişler, söz konusu değişkenin ekonomik büyüme ile arasındaki ilişkiyi GMM yöntemi ile incelemişlerdir. Ampirik modelden elde edilen bulgulara göre, 1998-2011 döneminde 27 Avrupa Birliği (AB) üyesi ülke için, finansal istikrarsızlığın ekonomik büyümeyi negatif yönde etkilediğini belirtmektedirler.

Ahmed vd. (2015) 1995-2013 döneminde MAGHREB ülkeleri için yaptıkları PVAR analizinden yararlandıkları çalışmalarında ekonomik büyümenin finansal gelişmeyi ve finansal istikrarı arttırdığını, finansal istikrarsızlığın ise ekonomik büyümeyi olumsuz yönde etkilediğini savunmaktadırlar.

Ceballas vd. (2015), 46 OECD ülkesi için yaptıkları çalışmada farklı krizler için farklı kukla değişkenlerden yararlanarak finansal istikrarsızlık ve pek çok farklı makro ekonomik değişken arasındaki ilişkiyi incelemişlerdir. Büyüme oranı, cari açık, doğrudan yabancı yatırım, tasarruflar, enflasyon, nüfus artı̧̧ oranı ve işsizlik gibi değişkenlerin finansal istikrarsızlık olan ilişkisin krizler bağlamında incelemişler ve finansal istikrarsızlık ile büyüme oranı arasında anlamlı şiddeti yüksek ve negatif bir ilişki olduğunu vurgulamışlardır. 


\section{Ampirik Model}

\subsection{Veri Setinin Tanımlanması ve Seçilen BRICT Ülkelerinin Yükselen Piyasa Ekonomileri Kapsamında Değerlendirilmesi}

Bu çalışmada "yükselen piyasa ekonomileri" olarak adlandıılan 1990'ı yılların başından itibaren finansal küreselleşme hareketleri ile ekonomik yapılarında neoliberal politikaları benimsemiş ülkeler BRIC+T ülkeleri analize konu edilmiştir. Söz konusu ekonomiler dünya ekonomisinin geleceği için ekonomik büyüme ve finansal istikrar açısından kilit rol üstlenmektedirler.

Finansal küreselleşme süreciyle yaygınlaşmasıyla birlikte yükselen piyasa ekonomilerinin kalkınma sürecinde ve önemli değişiklikler yaşandığı gözlemlenmektedir. Bretton Woods sonrası dönemde oluşturulan söz konusu politikaların amacı, ithal ikameci sanayileşme ve finansal baskılama gibi unsurlar ile devletin kalkınma sürecindeki etkin rol oynadığı ulusal devletçilik anlayışına son verilmesidir. Bahsedilen dönemde söz konusu politikalar devletin ekonomideki rolünün küçülmesi, ithal ikamesi yerine ihracat dayalı büyüme modelinin benimsenmesi ve ekonomiye serbest piyasa yapısının kazandırılması fikirlerine dayalı yeni bir kalkınma stratejisini önermekteydi. Oluşturulan bu strateji içinde devletin rolü ekonomik olarak kanun ve düzenin korunması, istikrarın sağlanması ve fiziki altyapının hizmetlerinin yerine getirilmesi ile sınırlandırımışt (Özdemir, 2013:90).

Küreselleşme ideolojisi azgelişmişlik ve kalkınma gibi kavramları iktisat yazınından çıkartmış yerine "yükselen piyasa ekonomileri (emerging market economies)" kavramını yerleştirmiştir. Dolayısıyla neoliberal politikalar kapsamında, kalkınma bir amaç olmaktan çıkartılmış, Goü’ler birer yükselen piyasa ekonomisine dönüştürülmüştür (Yeldan, 2008:20).

GOÜ'ler, finansal küreselleşme ile birlikte borçlanma olanaklarının artmasına paralel olarak, daha fazla yatırım firsatına ve dolayısıyla makroekonomik büyümelerini hızlandıracak olanaklara sahip olmuştur. Illk defa 1981 yılında Uluslararası Finans Kurumu (International Finance Coorporation-IFC) tarafindan kullanılmış olan "yükselen piyasa ekonomisi (emerging markets/emerging market economies)" terimi 1980'li yıllardan sonra yaygın olarak kullanılmaya başlamıştı (Kruger, 2002:1). IFC bu terimi GOÜ’lerde ihraç edeceği ilk yatırım fonunun tanıtımını yaparken bunu bir pazarlama aracı olarak kullanmıştır. Zaman içerisinde yaygınlık kazanan söz konusu terim, küresel ekonomi ile entegre olan ve finansal küreselleşme sürecinden büyüyerek çıkan gelişmekte olan ülkeleri ifade etmektedir (Özdemir, 2013:94).

"Yükselen Piyasa Ekonomileri" kavramı neoliberal politikalar kapsamında özelleştirme, finansal serbestleştirme ve kuralsızlaştırma uygulamalarıyla birlikte iktisat yazınına yerleşmiştir. Bu kavram, daha yalnızca neoliberal yapısal uyum programlarını benimseyen Goü'ler ile sosyalist sistem sonrası geçiş ekonomilerinin ifade eden bir tanımlama olarak kullanılmıştır. Ancak, finansal derinleşme arttıkça "yükselen piyasa ekonomisi" kavramı da bir tanımlamanın ötesine geçmiş, finansal küreselleşme sürecinin bir öğesi haline gelmiştir (Yeldan, 2008:110).

Yükselen piyasa ekonomileri genellikle, yüksek büyüme hızına sahip, piyasalarında getiri-risk düzeyi yüksek ve ayrıca finansal piyasada aşırı oynaklığa sahip olan ülkelerdir. Söz konusu ülkeler, finansal sistemlerini serbest piyasa ekonomisi doğrultusunda yeniden inşa etme çabası içerisinde olan, küresel ekonomi ile bütünleşme açısından önemli aşamalar kat etmiş, hızlı büyüme oranlarına sahip olan ve gelişmiş ülkeler safina katılmaya en yakın adaylar olan gelişmekte olan ülkelerdir. Yükselen piyasa ekonomileri dünya ekonomisiyle bütünleşme konusunda sergiledikleri başarının aksine, eğitim, nüfus artışı, yaşam beklentisi gibi demografik özelliklerde ve politik kurumlardaki yapısal sorunlar nedeni ile bu süreçte ciddi problemler ile karşı karşıya kalmaktadır (Yanar, 2008:23).

Goldman Sachs varlık yönetimi başkanı Jim O'Neill'ın Brezilya, Rusya, Hindistan ve Çin ülkelerinin yeni yatırım firsatı olarak ve daha iyi bir küresel ekonomik yapı oluşturulması amacıyla bir araya gelmelerini önermesi sonucunda "BRIC" kavramı ortaya çıkmıştır. Çalışma kapsamında Türkiye'de bu gruba dahil edilmiştir. BRICT ülkeleri popülasyonları, coğrafi alanları, ekonomik yapıları ve büyüme hızları açısından ortak özelliklere sahiptir. İş gücü açısından değerlendirildiğinde BRICT ülkeleri küresel ekonomide kilit bir rol 
üstlenmektedir. Goldman ve Sachs'a göre dünya nüfusunun yaklaşık olarak \%40'ını dünya GSYiH'nın yaklaşık \%25'ne sahip BRICT ülkeleri için 2050 yılında bu oran \%40 olacaktır (Akçay ve Erataş, 2012:5).

"BRIC" kavramı, adını Brezilya, Rusya, Hindistan (India) ve Çin (China) ekonomileri gibi son yıllarda yüksek hızda büyüyen ülkelerin baş harflerinden alan bir ekonomi terimidir. Kimi ekonomistler bu dörtlü gruba Güney Afrika'yı (South Africa) ekleyerek BRICS, kimileri ise Meksika'yı ekleyerek BRIMC gibi benzer ifadeler de kullanmaktadırlar. Hatta bir dönem Türkiye ekonomisinin istikrarlı olarak yüzde 10 dolaylarında büyümesi nedeniyle kimi ekonomistler tarafindan (örneğin 2011 yılında RBS Gelişen Piyasalar Başekonomisti Tim Ash) Türkiye'yi kastederek T-BRIC ifadesini de kullanılmıştır (Kowitt, 2009:1). Bu çalışmada BRIC ülkelerine ek olarak Türkiye'de analize dahil edilmiştir (Örmeci, 2013: 1).

"BRIC" ifadesi ilk olarak Goldman Sachs'ın baş ekonomisti Jim O'Neill tarafindan 2001 yılında yaptığı bir çalışma ile ekonomi yazınına kazandırımıştır (O'Neill, 2001:3). O'Neill çalışmasında, dünya coğrafyasının $\% 25$ ’ne sahip, dünya nüfusunun \%40'nı barındıran ve zengin doğal kaynakları bulunan bu dört ülkenin dünya ekonomisinde giderek büyüyen bir pay sahibi olacağını, dolayısıyla ekonomiye yön verme adına gelecekte daha çok rol üstleneceklerini vurgulamıştır (O'Neill, 2001:4-6). BRIC kelimesinin popülerolmasındaki en önemli pay; İngilizce "brick" tuğla kelimesini anımsatması ve söz konusu ülkelerin yeni dünya düzeninde önemli rol üsteleneceklerinin pek çok kişi tarafindan kabul edilmesidir.

Aşağıda yer alan tablolarda BRICT ülkelerine ait bazı makro ekonomik veriler yer almaktadır. BRICT ülkelerinin birbirine benzer ekonomik yapıları dikkati çekmektedir.

Tablo 2. BRICT Ülkeleri Ekonomik Büyüme Oranları (\%)

\begin{tabular}{cccccc}
\hline Büyüme Oranı & Brezilya & Rusya & Hindistan & Çin & Türkiye \\
\hline 2000 & 4.388 & 10.046 & 3.975 & 8.4 & 6.64 \\
2001 & 1.39 & 5.09 & 4.944 & 8.3 & -5.962 \\
2002 & 3.053 & 4.744 & 3.907 & 9.1 & 6.43 \\
2003 & 1.141 & 7.349 & 7.944 & 10 & 5.608 \\
2004 & 5.76 & 7.176 & 7.849 & 10.1 & 9.644 \\
2005 & 3.202 & 6.376 & 9.285 & 11.3 & 9.01 \\
2006 & 3.962 & 8.154 & 9.264 & 12.7 & 7.11 \\
2007 & 6.07 & 8.535 & 9.801 & 14.2 & 5.03 \\
2008 & 5.094 & 5.248 & 3.891 & 9.6 & 0.845 \\
2009 & -0.126 & -7.821 & 8.48 & 9.2 & -4.704 \\
2010 & 7.528 & 4.504 & 10.26 & 10.606 & 8.487 \\
2011 & 3.974 & 5.066 & 6.638 & 9.5 & 11.113 \\
2012 & 1.921 & 3.656 & 5.456 & 7.9 & 4.79 \\
2013 & 3.005 & 1.785 & 6.386 & 7.8 & 8.491 \\
2014 & 0.504 & 0.739 & 7.505 & 7.3 & 5.167 \\
2015 & -3.769 & -2.828 & 8.01 & 6.9 & 6.086 \\
2016 & -3.595 & -0.225 & 7.107 & 6.7 & 3.184 \\
\hline
\end{tabular}

Kaynak: IMF, Wolrd Economic Outlook, 2017.

Tablo 2' de yer alan veriler incelendiğinde en yüksek büyüme oranlarının Çin ve Hindistan'a ait olduğu görülmektedir. Likidite bolluğu yaşanan 2000'li yılların başında hemen hemen her ülkenin büyüme rakamlarında bir artış olduğu gözlemlenmektedir. Ayrıca uluslararası finansal krizin etkileri tüm ülkelerin büyüme rakamlarına yansımışttr. Ekonomik büyümesi gerileyen Çin ve Hindistan hariç diğer BRICT ülkelerinde negatif büyüme rakamları ile karşı karşıya kalınmaktadır. Son yıllara bakıldığında ise genel olarak ekonomik 
daralmanın yaşandığı hatta Brezilya ve Rusya'da yeniden negatif büyüme rakamlarınla karşı karşıya kalındığı görülmektedir.

Tablo 3. BRICT Ülkeleri Yatırım Oranları (\%GSYIH)

\begin{tabular}{|c|c|c|c|c|c|}
\hline Yatırımlar & Brezilya & Rusya & Hindistan & Çin & Türkiye \\
\hline 2000 & 18.903 & 18.39 & 24.263 & 34.328 & 23.8 \\
\hline 2001 & 18.742 & 20.569 & 24.244 & 36.296 & 18.135 \\
\hline 2002 & 17.449 & 19.38 & 24.75 & 36.903 & 21.243 \\
\hline 2003 & 16.857 & 18.982 & 26.831 & 40.369 & 22.474 \\
\hline 2004 & 17.913 & 19.301 & 32.818 & 42.657 & 25.205 \\
\hline 2005 & 17.205 & 18.543 & 34.65 & 40.982 & 27.034 \\
\hline 2006 & 17.816 & 20.139 & 35.659 & 40.606 & 29.565 \\
\hline 2007 & 19.819 & 24.089 & 38.114 & 41.239 & 28.714 \\
\hline 2008 & 21.619 & 22.844 & 34.305 & 43.21 & 28.936 \\
\hline 2009 & 18.796 & 15.564 & 36.48 & 46.335 & 23.018 \\
\hline 2010 & 21.801 & 20.3 & 36.502 & 47.881 & 26.973 \\
\hline 2011 & 21.826 & 24.405 & 39.59 & 48.006 & 31.269 \\
\hline 2012 & 21.417 & 24.777 & 38.348 & 47.18 & 28.304 \\
\hline 2013 & 21.976 & 23.672 & 34.024 & 47.251 & 29.773 \\
\hline 2014 & 21.03 & 22.241 & 34.567 & 46.775 & 29.033 \\
\hline 2015 & 19.133 & 22.138 & 32.904 & 44.748 & 28.362 \\
\hline 2016 & 17.523 & 25.316 & 30.376 & 44.181 & 28.227 \\
\hline
\end{tabular}

Kaynak: IMF, Wolrd Economic Outlook, 2017.

Tablo 4. BRICT Ülkeleri Tasarruf Oranları (\%GSYiH)

\begin{tabular}{llllll}
\hline Tasarruf Oranları & Brezilya & Rusya & Hindistan & Çin & Türkiye \\
\hline 2000 & 15.12 & 34.654 & 23.703 & 36.01 & 20.84 \\
2001 & 14.506 & 30.3 & 24.932 & 37.59 & 20.688 \\
2002 & 15.861 & 26.78 & 25.961 & 39.301 & 21.666 \\
2003 & 17.53 & 26.147 & 29.109 & 42.946 & 19.922 \\
2004 & 19.608 & 28.523 & 32.476 & 46.163 & 21.477 \\
2005 & 18.724 & 28.827 & 33.463 & 46.715 & 22.856 \\
2006 & 18.993 & 28.819 & 34.651 & 48.963 & 23.948 \\
2007 & 19.849 & 29.259 & 36.843 & 51.128 & 23.252 \\
2008 & 19.813 & 28.669 & 32.025 & 52.344 & 23.98 \\
2009 & 17.223 & 19.4 & 33.665 & 51.084 & 21.426 \\
2010 & 18.368 & 24.417 & 33.701 & 51.802 & 21.334 \\
2011 & 18.879 & 29.146 & 35.402 & 49.815 & 22.449 \\
2012 & 18.405 & 28.002 & 33.541 & 49.693 & 22.786 \\
2013 & 18.948 & 25.128 & 32.286 & 48.79 & 23.179 \\
2014 & 16.789 & 25.028 & 33.251 & 49.015 & 24.413 \\
2015 & 15.834 & 27.177 & 31.848 & 47.457 & 24.777 \\
2016 & 16.215 & 27.306 & 29.703 & 45.929 & 24.505 \\
\hline
\end{tabular}

Kaynak: IMF, Wolrd Economic Outlook, 2017. 
Tablo 3'te yer alan veriler ışığında en yüksek yatırım oranının Çin'de olduğu görülmektedir. Hindistan Türkiye ve Çin'i takip etmektedir. Küresel finansal krize kadar Çin hariç genel eğilim olarak tüm ülkelerde yatırımların arttğı ancak küresel finans krizinin hemen ardından yatırımların azaldığı görülmektedir. Kriz sonrası bir toparlanma yaşansa da son yıllarda yeniden yatırım oranlarının azalmaya başladığı dikkati çekmektedir.

Tablo 4'te yer alan verilere göre en yüksek tasarruf oranları Çin'de görülmektedir. Sırasıyla Hindistan, Rusya, Türkiye ve Brezilya Çin'i takip etmektedir. Küresel finansal krize kadar Çin hariç genel eğilim olarak tüm ülkelerde tasarrufların arttğı ancak küresel finans krizinin hemen ardından yatırımların azaldığı görülmektedir. 2012 yılı sonrasında ise Türkiye hariç diğer ülkelerde tasarruf oranlarının gittikçe azaldığı dikkati çekmektedir.

Tablo 5. BRICT Ülkeleri Cari Denge Oranları (\%GSYiH)

\begin{tabular}{|c|c|c|c|c|c|}
\hline Cari Denge & Brezilya & Rusya & Hindistan & Çin & Türkiye \\
\hline 2000 & -3.783 & 16.264 & -0.559 & 1.682 & -3.633 \\
\hline 2001 & -4.236 & 9.731 & 0.688 & 1.295 & 1.877 \\
\hline 2002 & -1.588 & 7.401 & 1.211 & 2.397 & -0.263 \\
\hline 2003 & 0.674 & 7.165 & 2.277 & 2.576 & -2.422 \\
\hline 2004 & 1.695 & 9.222 & -0.342 & 3.506 & -3.507 \\
\hline 2005 & 1.519 & 10.284 & -1.187 & 5.734 & -4.186 \\
\hline 2006 & 1.176 & 8.679 & -1.008 & 8.357 & -5.659 \\
\hline 2007 & 0.029 & 5.17 & -1.27 & 9.889 & -5.474 \\
\hline 2008 & -1.807 & 5.824 & -2.28 & 9.134 & -5.156 \\
\hline 2009 & -1.573 & 3.835 & -2.815 & 4.75 & -1.762 \\
\hline 2010 & -3.433 & 4.117 & -2.802 & 3.92 & -5.777 \\
\hline 2011 & -2.947 & 4.741 & -4.188 & 1.809 & -8.937 \\
\hline 2012 & -3.012 & 3.225 & -4.806 & 2.513 & -5.49 \\
\hline 2013 & -3.028 & 1.455 & -1.737 & 1.538 & -6.695 \\
\hline 2014 & -4.242 & 2.787 & -1.316 & 2.241 & -4.667 \\
\hline 2015 & -3.299 & 5.039 & -1.057 & 2.709 & -3.737 \\
\hline 2016 & -1.308 & 1.991 & -0.673 & 1.748 & -3.777 \\
\hline
\end{tabular}

Kaynak: IMF, Wolrd Economic Outlook, 2017.

Tablo 5'te yer alan veriler ışığında Çin ve Rusya hariç diğer BRICT ülkelerinde cari açık olgusu ile karşı karşıya kalındığı görülmektedir. Çin ve Rusya'daki pozitif cari denge rakamları da dahil olmak üzere tüm ülkeler için uluslararası finansal krizin etkileri açıkça görülmektedir. BRICT ülkelerinin tümünde uluslararası finansal krizden sonra cari denge bozulmuş Hindistan Brezilya Ve Türkiye'de cari açık oranları artmıştır. Son yıllarda söz konusu ülkeler adına genel bir toparlanmanın olduğu gözlemlenmektedir.

Ampirik model kapsamında, yükselen piyasa ekonomisi olarak nitelendirilen 5 ülke (BRICT: Brezilya, Çin, Hindistan, Rusya ve Türkiye) için World Bank Global Financial Development veri tabanından elde edilen veriler 2001-2014 dönemine aittir. Veri kısıtı nedeniyle ancak bu zaman dilimi çalışmaya dahil edilebilmiştir, ancak belirtilen dönem aralı̆ında söz konusu ülkelere ait veriler dengeli bir şekilde paneli oluşturacak seriler halinde mevcuttur. Elde edilen yıllık veriler ile ekonometrik bir model oluşturulmuştur. Veriler Dünya Bankası ve IMF veri tabanlarından elde edilmiştir. 


$$
G D P_{i t}=\beta_{0}+\beta_{1} F I I_{i t}+u_{i t}
$$

Yukarıda yer alan 1 numaralı denklemde,

$G D P_{i t}$ : Sabit fiyatlarla Gayri Safi Yurtiçi Hasıla (GSYIH) \% değişim oranını

$F I I_{i t}$ : Finansal istikrarsızlık endeksini (\% değişim) ifade etmektedir.

\subsection{Değişkenlerin Homojenliğinin Araştırılması}

Çalışmanın ampirik model kısmında, öncelikle değişkenlerin heterojen ya da homojen olup olmadıkları incelenmektedir. Değişkenlerin sahip olduğu heterojenlik özelliği, analizin ilerleyen aşamalarında uygulanacak olan birim kök ve eşbütünleşme testlerinin yapısını değiştirmektedir. Söz konusu özelliğin belirlenmesi için kullanılan delta testi aşağıdaki şekilde hesaplanmaktadır (Pesaran ve Yamagata, 2008:56):

$$
\begin{aligned}
& \tilde{\Delta}=\sqrt{N} \frac{N^{-1} \check{S}-k}{\sqrt{2 k}} \\
& \tilde{\Delta}_{a d j}=\frac{\sqrt{N} N^{-1} \check{S}-k}{\sqrt{\operatorname{Var}(T, k)}}
\end{aligned}
$$

$\tilde{\Delta}$ Küçük örneklemler için $\tilde{\Delta}_{a d j}$ ise büyük örneklemler için kullanılmaktadır.

Yukarıda yer alan 2 ve 3 numaralı denklemlerde " $\operatorname{Var}(T, k)$ " varyansı, " $k$ " açıklayıcı değiş̧ken sayısını, "S" Swamy test istatistiğini, "N" gözlem sayısını ifade etmektedir. Delta testine ait boş hipotez ve alternatif hipotez aşağıdaki gibidir: (Pesaran ve Yamagata, 2008:57-58).

$$
\begin{gathered}
H_{0}: \beta_{1}=\beta_{2}=\cdots=\beta_{n}=\beta\left(\text { tüm } \beta_{i}^{\prime} \text { ler } i c ̧ i n\right) \\
H_{1}: \beta_{1} \neq \beta_{2} \neq \cdots \neq \beta_{n} \quad\left(\text { en az bir } \beta_{i} \text { için }\right)
\end{gathered}
$$

Tablo6. Delta Test Sonuçları

\begin{tabular}{ccc}
\hline Test & Test i̇statistiği & Prob. \\
\hline$\tilde{\Delta}$ & 0.881 & 0.189 \\
\hline$\tilde{\Delta}_{a d j}$ & 0.965 & 0.167 \\
\hline
\end{tabular}

Tablo 6 'da yer alan test sonuçlarına göre, hesaplanan katsayılar \%5 anlamlılık düzeyinde anlamlı değildir ve $\mathrm{H}_{0}$ red edilir. Paneli oluşturan değişkenler homojendir.

\subsection{Yatay Kesit Bağımlılığının Araştırılması}

Paneli oluşturan serilere belli bir şok geldiğinde örneklemde yer alan tüm yatay kesit birimlerinin söz konusu şoktan aynı derecede etkilenip etkilenmediği araştırılmalıdır. Kalıntılar arasında eşanlı bir korelasyon beklenmekte ve ilgili korelasyonun anlamlılı̆ı istatistiki olarak incelenmektedir, buna yatay kesit bağımlılığı adı verilmektedir (Ün, 2016:77).

Değişkenlerin homojenlik ve yatay kesit bağımlılığı özelliği gelecek aşamalarda uygulanması gereken birim kök ve eşbütünleşme testlerinin türünü belirlemektedir. Bu çalışmada, yatay kesit bağımlılığının incelenmesi için Pesaran $C D_{L M}$ testi kullanılmıştır (Pesaran, 2004:4):

$$
\Delta Y_{i t}=a_{i}+b_{i} Y_{i, t-1}+\sum_{j=1}^{p_{i}} c_{i j} \Delta Y_{i, t-j}+d_{i} t+h_{i} \bar{Y}_{t-1}+\sum_{j=0}^{p_{i}} \eta_{\ddot{\mathrm{u}}} \Delta \bar{Y}_{i, t-j}+\varepsilon_{i, t}
$$

Yukarıda yer alan 4 numaralı denklemde $t$ trendi, $p_{i}$ ise yatay kesit birimlerine göre en uzun gecikme sayısını, $\alpha$ ortak zaman etkisini, $b, c, d$ ve $h$ ise değişkenlere ait tahmin edilen regresyon katsayılarını ifade etmektedir (Akçay ve Erataş, 2015:92). $C D_{L M}$ testinde modele ait kalıntılar arasında az ya da çok, eş anlı bir 
ilişkinin olduğu varsayılmaktadır. Söz konusu test kapsamında, model için tahmin edilen arthklar kullanılarak basit korelasyon katsayılarının sıfira eşit olup olmadığı incelenmektedir (Şak, 2016:222).

Söz konusu ilişkinin istatistiksel anlamlılığı Breusch ve Pagan (1980) LM testi ile sınanmaktadır. $C D_{L M}$ test istatistiği aşağıdaki gibi ifade edilmektedir (Pesaran, 2004:4).:

$$
C D_{L M}=T \sum_{i=j}^{N-1} \sum_{j=i+1}^{N} \hat{p}_{i j}^{2} \sim \chi_{N(N-1) / 2}^{2}
$$

6 numaralı denklemde $p_{i j}$ ile ifade edilen katsayı, her bir denklemin En Küçük Karaler (EKK) ile tahmin edilmesinden elde edilen kalıntılar arasındaki korelasyon katsayısıdır.

Pesaran (2004) hem $T$ ve hem de $N$ 'nin büyük olduğu durumlar için $C D_{L M}$ test istatistiğini türetmiştir, ardından Pesaran vd. (2008) $C D_{L M}$ testinin gücünü attırmışlardır ve Pesaran ve Yagamata'ya (2008) göre test küçük örneklemlerde de kullanılabilmektedir (Pesaran, 2004:5; Pesaran vd.:2008:106, Pesaran ve Yamagata:2008:51).

$$
C D_{L M}=\sqrt{\frac{1}{N(N-1)}} \sum_{i=j}^{N-1} \sum_{J=i+1}^{N}\left(T \hat{p}_{i j}^{2}-1\right) \sim N(0,1)
$$

Kalıntılar arasında korelasyonun olmadığı şeklindeki boş hipotez altında, zaman $(T)$ sonsuza giderken ve yatay kesit sayısı $(N)$ sabitken $C D_{L M}$ istatistiği ki-kare $\chi^{2}$ dağılımı göstermektedir. $C D_{L M}$ testine ait sıfır hipotezi yatay kesitler arasında bağımlılığının olmadığını belirtirken, alternatif hipotez ise yatay kesitler arası bağımlılığı ifade etmektedir.

$$
\begin{gathered}
H_{0}: p_{i j}=p_{j i}=\operatorname{cor}\left(u_{i t}, u_{j t}\right)=0, \quad i \neq j \\
H_{1}: p_{i j}=p_{j i} \neq 0, \quad i \neq j
\end{gathered}
$$

Tablo 7. Model için $C D_{L M}$ Testi Sonuçları

\begin{tabular}{lcc}
\hline CD Test & Test İstatistiği & Prob \\
\hline LM (Breusch, Pagan 1980) & 28.037 & 0.002 \\
CD LM 1 (Pesaran 2004) & 4.033 & 0.000 \\
CD LM 2 (Pesaran2004) & 4.128 & 0.000 \\
Bias-adjusted CD (Pesaran vd. 2008) & -0.704 & 0.759 \\
\hline
\end{tabular}

Model için $C D_{L M}$ testinden elde edilen sonuçlara göre, sıfir hipotezi reddedilir. Yatay kesit birimleri arasında bağımlılık vardır.

Tablo 8. GDP Değişkeni İçin $C D_{L M}$ Testi Sonuçları

\begin{tabular}{lrl}
\hline CD Test & Test İstatistiği & Prob \\
\hline LM (Breusch, Pagan 1980) & 20.141 & 0.028 \\
CD LM 1 (Pesaran 2004) & 2.268 & 0.012 \\
CD LM 2 (Pesaran 2004) & -2.455 & 0.007 \\
Bias-adjusted CD (Pesaran vd. 2008) & 2.384 & 0.009 \\
\hline
\end{tabular}

GDP değişkeni için $C D_{L M}$ testinden elde edilen sonuçlara göre, sıfir hipotezi reddedilir. Yatay kesit birimleri arasında bağımlılık vardır. 
Tablo 9. Fll Değişkeni İ̧̧in $C D_{L M}$ Testi Sonuçları

\begin{tabular}{lcc}
\hline CD Test & Test İstatistiği & Prob \\
\hline LM (Breusch, Pagan 1980) & 20.698 & 0.023 \\
CD LM 1 (Pesaran 2004) & 2.392 & 0.008 \\
CD LM 2 (Pesaran 2004) & -2.111 & 0.017 \\
Bias-adjusted CD (Pesaran vd. 2008) & 4.459 & 0.000 \\
\hline
\end{tabular}

Fll değişkeni için $C D_{L M}$ testinden elde edilen sonuçlara göre, sıfir hipotezi reddedilir. Yatay kesit birimleri arasında bağımlılık vardır.

\subsection{Durağanlığın Araştırılması}

Panel veri analizi ile hem birimlere hem de zamana ait bilgiler analize dahil edilmektedir. Verilerin kesit boyutunun yanı sıra zaman boyutunun da analizlerde yer almasıyla birlikte serilerin zaman içerisinde izlediği yol önem kazanmaktadır. Panel verilerdeki zaman etkisinin incelenmesiyle panel veriyi yaratan sürecin durağan olup olmadığı belirlenebilmektedir.

Panel birim kök testlerinin zaman serisi birim kök testlerinden en büyük farkı hem zaman hem de yatay kesit boyutu ile panel verilerin asimptotik davranış sergileyebilecek olmasıdır. Panel serilerde birimler arasında korelasyon olursa, testlerin asimptotik özellikleri etkilenebilecektir. Bu nedenle, birimler arası korelasyonun varlığına göre birim kök testleri geliştirilmiştir. İlgili yazında birimler arası korelasyonun olmadığı durum için geliştirilen testler birinci nesil panel birim kök testleri olarak adlandırılırken, birimler arasında korelasyonun varlı̆ı̆ında kullanılan testler ise ikinci nesil panel birim kök testleri olarak adlandırımaktadır (Şak, 2016:204). íkinci nesil panel birim kök testleri, birimler arasındaki kesitsel bağlıı̆ı dikkate alarak durağanlığı incelemektedir.

Pesaran (2007) hata terimlerinin faktör yüklemelerinin tahmin etmek yerine birimler arası bağımlılığı yok etmek için uygulama kolaylığı sağlayan başka bir yöntem önermiştir. Bu yöntemde zaman serilerinde kullanılan ADF (Augmented Dickey Fuller) testinin gecikmeli yatay kesit ortalamaları ile genişletilmiş hali kullanılmaktadır ve bu da birimler arası korelasyonu yok etmektedir. Pesaran (2007) tarafindan geliştiren yatay kesit bağımlılığını dikkate alan bu ikinci nesil panel birim kök testi CADF (Cross-Sectionally Augmented Dickey-Fuller) "Kesitsel Olarak Genişletilmiş Dickey Fuller Testi" olarak adlandırılmaktadır.

$C A D F$ testi aşağıda yer alan regresyon denkleminin tahminine dayanmaktadır (Pesaran 2007: 268);

$$
\Delta Y_{i t}=\alpha_{i}+b_{i} y_{i, t-1}+\sum_{j=1}^{\rho_{i}} c_{i j} \Delta Y_{i, t-j}+d_{i} t+h_{i} \bar{y}_{i, t-j}+\sum_{j=0}^{\rho_{i}} \eta_{\ddot{\mathrm{u}}} \Delta \bar{y}_{i, t-j}+\varepsilon_{i, t}
$$

$H_{0}: b_{i}=0$, seri durağandır boş hipotezi altında gözlem sayısı $N \rightarrow \infty$ giderken ve ortak öğe olan $\bar{y}_{t} \neq 0$ ile kendisinin gecikmeli değerleri olan $\Delta \bar{y}_{t}$ 'nin birbirine yaklaşabileceği ifade edilmektedir. Buradaki temel amaç her bir yatay kesit için hata terimindeki otokorelasyonu dikkate almaktadır. Ayrıca bu test hem $\mathrm{N}>\mathrm{T}$ durumunda hem de $\mathrm{T}>\mathrm{N}$ durumunda kullanılabildiği gibi küçük örneklemlerde de güçlü sonuçlar vermektedir (Güloğlu ve İvrendi 2010: 383; Pesaran, 2007:266).

Tahmin edilen regresyon katsayıları için elde edilen t-istatistikleri, Pesaran (2007) tablo değerleri ile karşılaştırılarak karar verilmektedir. $C A D F$ testi ile gözlem sayısının zaman boyutundan büyük veya küçük olması durumunda geçerli sonuçlar elde edilmektedir. CIPS istatistiği ise her bir yatay kesit için hesaplanan $\mathrm{t}$-istatistik değerinin ortalamasını temsil etmektedir.

CADF testine ait t istatistiği aşağıdaki şekilde hesaplanmaktadır (Pesaran, 2007:269):

$$
t_{i}(N, T)=\frac{\Delta \hat{Y}_{l} \bar{M}_{w} Y_{i-1}}{\hat{\sigma}\left(\hat{Y}_{i-1} \bar{M}_{w} Y_{i-1}\right)^{1 / 2}}
$$


CADF testine ait CIPS istatistiği aşă̆ıdaki şekilde hesaplanmaktadır (Pesaran, 2007:269):

$\bar{t}=N^{-1} \sum_{i=1}^{N} t_{i}(N, T)$

CADF testine ait sıfir ve alternatif hipotezler ise aşağıda yer alan şekilde ifade edilmektedir. Sıfir hipotezi serinin durağan olduğunu belirtirken alternatif hipotez ise serinin durağan olmadığını ifade etmektedir (Pesaran, 2007:276):

$$
\begin{aligned}
& H_{o}: b_{\mathrm{I}}=0 \\
& H_{1}: b_{i}<0 \quad \dot{\mathrm{I}}=1,2,3 \ldots, N .
\end{aligned}
$$

Tablo 10. CADF Testi Sonuçları

\begin{tabular}{|c|c|c|}
\hline & GDP & FII \\
\hline Brezilya & 1.369 & -1.870 \\
\hline Çin & -1.840 & -3.321 \\
\hline Hindistan & -2.811 & -2.846 \\
\hline Rusya & -0.802 & -5.126 \\
\hline Türkiye & -1.587 & -5.818 \\
\hline CIPS & -1.134 & -3.796 \\
\hline
\end{tabular}

\section{CADF T-istatistik Değerleri}

Tablo 10'da yer alan sonuçlar değerlendirildiğinde GDP değişkenine ait CIPS istatistiği değerlerinin (veriler homojen olduğu için CIPS istatistiği dikkate alınmıştir) kritik değer olan -3.51'den büyük olduğu bu nedenle serilerin birim kök içerdiği yani durağan olmadığı sonucuna ulaşılmaktadır (Pesaran, 2007:281). FII değişkeni için hesaplanan CIPS test değeri kritik değerden küçüktür bu durumda serinin durağan olduğu sonucunu göstermektedir fakat küçük örneklemlerde sıfir ve alternatif hipotezlerin yerleri nedeniyle kimi zaman sapmalı sonuçlar elde edilmektedir. Bu durumun önüne geçmek amacıyla, durağanlık testinin güvenilirliği açısından, bir panel birim kök testine daha başvurulmuştur.

Panel durağanlık testlerinde, küçük örneklem söz konusu olduğunda olası sahte birim kök sorununun ortadan kaldırıması için panel KPSS testi uygulanmaktadır. Hadri Kurozumi (2012) birim kök testi; KPSS testinin panel veri setleri için uyarlanmış halidir, yatay kesit bağımlıı̆ı̆ın dikkate alır ve Pesaran (2007)'den yola çıkılarak geliştirilmiştir. Hadri Kurozumi (HK) birim kök testinde CADF'te olanın aksine boş hipotezde serinin durağan olmadığı ifade edilmektedir. Bu durumda HK testi CADF'nin güçsüz kaldığı durumlarda kullanılabilmekte ve sahte birim kökün varlığının önüne geçmiş olmaktadır. HK testinin tahmin edildiği regresyon denklemleri aşağıda yer almaktadır (Hadri ve Kurozumi 2012: 31);

$$
\begin{aligned}
& y_{i t}=z^{\prime}{ }_{t} \delta_{i}+f_{t} \gamma_{i}+\varepsilon_{i t} \\
& \varepsilon_{i t}=\emptyset_{i p} \varepsilon_{i t-1}+\cdots+\emptyset_{i 1} \varepsilon_{i t-p}+v_{i t}
\end{aligned}
$$

$i=1, \ldots, N$ ve $t=1, \ldots, T$ iken $z_{t}$ deterministik yani hesaplanabilir ve bağımlı değişkendeki değişimi açıklayabilmektedir. Bu test için iki farklı test istatistiği hesaplanmaktadır. Bunlar, her ikisi de sonsuza yaklaşırken normal dağılıma sahip olduğu varsayılan $Z_{A}^{S P C}$ ve $Z_{A}^{L A \prime}$ dir. $Z_{A}^{S P C}$ küçük örneklemler için kullanılırken, $Z_{A}^{L A}$ büyük örneklemler için de kullanılmaktadır (Hadri Kurozumi, 2012:33).

$Z_{A}^{S P C}$, uzun dönem varyansının; Sul ve diğerleri (2005) tarafindan geliştirilen yöntemle hesaplanan HK testi istatistiğidir. $Z_{A}^{L A}$, uzun dönem varyansın Choi (1993) ile Toda ve Yamamato (1995) yöntemiyle hesaplandığı HK testi istatistiğidir. 
Tablo 11. GDP Hadri Kurozumi Testi Sonuçları

\begin{tabular}{crl}
\hline & Test İstatistiği & Prob \\
\hline$Z_{A}^{S P C}$ & -0.4458 & 0.6721 \\
$Z_{A}^{L A}$ & 26.0882 & 0.0000 \\
\hline
\end{tabular}

Tablo 12. Fll Hadri Kurozumi Testi Sonuçları

\begin{tabular}{ccl}
\hline & Test İstatistiği & Prob \\
\hline$Z_{A}^{S P C}$ & 1.0310 & 0.1513 \\
$Z_{A}^{L A}$ & 0.9919 & 0.1606 \\
\hline
\end{tabular}

Tablo 11 ve 12 birlikte değerlendirildiğinde GDP ve FII değişkeni için HK test istatistiklerinin anlamsız olduğu görülmektedir. Bu bağlamda hesaplanan değerler 0.05 'ten büyük olan HK T-istatistikleri için sıfir hipotezi red edilemez ve değişkenlerin durağan olmadığı, serilerin birim kök içerdiği sonucuna varılmaktadır.

\subsection{Eşbütünleşme İlişkisinin Araştırılması}

İktisadi değişkenlere ait serilerin durağan olmadığı birim kök içerdiği durumlarda, söz konusu serilerin doğrusal bileşimleri durağan olabilmekte ve seriler uzun dönemde birbiri ile ilişkili olabilmektedir. Sistemi etkileyen şoklara rağmen değişkenler arasında uzun dönemde bir ilişkinin varlığı mümkün olmakta ve söz konusu ilişkinin test edilmesi gerekmektedir (Yerdelen-Tatoğlu, 2012:233).

Çalışmada yer alan değişkenler hem homojen hem de yatay kesit bağımlığı özelliği taşımaktadır, bu nedenle değişkenler arası eşbütünleşme ilişkisinin araştrııması amacıyla hata düzeltme modeli temelli Durbin Hausman (DH) panel eşbütünleşme testi tercih edilmiştir. Bu test ortak faktör sayesinde yatay kesit bağımlılığını dikkate almaktadır. Ayrıca bu test küçük örneklemlerde dahi güçlü sonuçlar vermektedir (Westerlund, 2008:195).

Durbin-Hausman testinde yer alan ortak faktör ile yatay kesit bağımlıı̆̆ı dikkate alınmaktadır. Durbinh testi $T>N$ olduğu durumlarda da kullanılmaktadır (Westerlund, 2008: 199);

$$
\begin{aligned}
& z_{i t}=\dot{\lambda}_{i} F_{t}+e_{i t} \\
& F_{j t}=\rho_{j} F_{j t-1}+u_{j t-1} \\
& e_{i t}=\phi_{i} e_{i t-1}+v_{i t}
\end{aligned}
$$

Yukarıda yer alan 13 numaralı denklemde $F_{t}$ ortak faktörü temsil etmektedir ve $F_{j t}$ 'nin $k$ boyutlu şeklidir. $j=(1,2, \ldots, k)$ iken yukarıdaki 13 numaralı denklemde yer alan $\rho_{j}<1$ (tüm j'ler için) olduğunda $F_{t}$ durağandır (Westerlund 2008: 200);

DH testine ait iki farklı test istatistiği hesaplanmaktadır. Bunlar; DHg heterojenite varlığında dikkate alınırken, $\mathrm{DH}_{\mathrm{p}}$ homojenite varlığında dikkate alınmaktadır. Sıfır hipotezi tüm yatay kesit birimleri için eşbütünleşme olmadığını iddia etmektedir.

DH testine ait istatistikler aşağıdaki gibi hesaplanmaktadır (Westerlund, 2008:203):

$$
\begin{aligned}
& \mathrm{DH}_{\mathrm{g}}=\sum_{\mathrm{i}=1}^{\mathrm{n}} \widehat{\mathrm{S}}_{\mathrm{i}}\left(\widetilde{\phi}_{\mathrm{i}}-\widehat{\phi}_{\mathrm{i}}\right)^{2} \sum_{\mathrm{t}=2}^{\mathrm{T}} \hat{\mathrm{e}}_{\mathrm{it}-1}^{2} \\
& \mathrm{DH}_{\mathrm{p}}=\widehat{\mathrm{S}}_{\mathrm{n}}(\widetilde{\phi}-\widehat{\phi})^{2} \sum_{\mathrm{i}=1}^{\mathrm{n}} \sum_{\mathrm{t}=1}^{\mathrm{T}} \hat{\mathrm{e}}_{\mathrm{it}-1}^{2}
\end{aligned}
$$


DH testine ait sıfir ve alternatif hipotezler aşağıda yer almaktadır (Westerlund, 2008:203):

$\mathrm{H}_{0}: \phi_{\mathrm{i}}=1$ tüm eşbütünleşme ilişkisi yoktur (tüm i'ler için)

$\mathrm{H}_{1 \mathrm{a}}: \phi_{\mathrm{i}}=\phi<1$ eşbütünleşme ilişkisi vardır (tüm i’ler için)

$\mathrm{H}_{1 \mathrm{~b}}: \phi_{\mathrm{i}}<1$ eşbütünleşme ilişkisi vardır (tüm i’ler için)

Tablo 13. Durbin-H Eşbütünleşme Testi Sonuçları

\begin{tabular}{ccc}
\hline & Test İstatistiği & Prob \\
\hline $\boldsymbol{D H g}$ & 94.353 & 0.000 \\
$\boldsymbol{D H p}$ & 5.451 & 0.000 \\
\hline
\end{tabular}

Tablo 13'te yer alan bulgulara göre GDP ve Fll değişkeni arasında eşbütünleşik bir ilişkinin varlığı ispatlanmaktadır. Değişkenler homojen oldukları için $\mathrm{DH}_{\mathrm{p}}$ istatistiği dikkate alınmıştır. $\mathrm{DH}_{\mathrm{p}}$ değişkenine ait değer 0.05 'ten küçüktür ve bu da sıfir hipotezinin reddi anlamına gelmektedir. Sonuç olarak GDP ve FII değişkeni arasında eşbütünleşik bir ilişki vardır ve uzun dönemde söz konusu değişkenler birlikte hareket etmektedir.

\subsection{Uzun Dönem Regresyon Katsayı Tahmini: Ortak ilişkili Etkiler Modeli}

Bu çalışmada modele ait uzun dönem katsayılarının tahminlenmesi için, Pesaran (2006) Ortak ilişkili Etkiler Modeli (Common Correlated Effects Model-CCE) kullanılmıştır. Söz konusu yöntem, her bir yatay kesit birimi için regresyon katsayılarının tahminlenmesini sağlamaktadır (Pesaran, 2006:2-3).

CCE modeli hem $\mathrm{N}>\mathrm{T}$ hem de $\mathrm{T}>\mathrm{N}$ olduğu durumlarda kullanılabilmektedir, ayrıca söz konusu model tahmincileri küçük örneklemlerde de güçlü sonuçlar vermektedir (Pesaran ve Tosetti, 2011:192). Yatay kesit bağımlıı̆ııın dikkate alındığı modelde, değişkenlerin aynı ya da farklı durağanlık derecelerinin de analiz edilmesi mümkündür (Pesaran ve Yamagata, 2012:26).

CCE modelinde, ilk olarak grup ortalamasını veren katsayılar, bağımlı ve bağımsız değişkene ait yatay kesit birimlerinin ortalaması olarak tahmin edilmektedir (Pesaran, 2006:13).

$$
y_{i t}=\alpha+b x_{i t}+\sum_{j=2}^{N} d_{j} D_{j}+\sum_{j=1}^{N} c_{1 i}\left\{\overline{y_{t}} D_{j}\right\}+\sum_{j=1}^{N} c_{2 i}\left\{\overline{x_{t}} D_{j}\right\}+e_{i t}
$$

17 numaralı denklemdeki sırasıyla $\alpha, b x_{i t}, D_{j}$ standart sabit etkiler yaklaşımına ait tahmincilerdir. Bahsedilen denklemde yer alan son iki terim olan, $\sum_{j=1}^{N} c_{1 i}\left\{\overline{y_{t}} D_{j}\right\}$ ve $\sum_{j=1}^{N} c_{2 i}\left\{\overline{x_{t}} D_{j}\right\}$ her bir yatay kesit birimi için oluşturulan kukla değişken $D_{j}{ }^{\prime}$ ler yoluyla yatay kesit birimlerinin zamana (t) göre ortalaması $\overline{z_{t}}=$ $N^{-1} \sum_{i=1}^{N} z_{i t}$ ile olan ilişkisini göstermektedir (Eberhardt ve Teal, 2009:12). Bu denklemden (NT x N) boyutunda $\mathrm{k}+1$ matris ortaya çıkmaktadır (Erataş, 2012: 47).

CCE modeline ait ortak grup tahmincileri aşağıdaki denklemden yola çıkarak hesaplanmaktadır:

$$
C C E_{M G} y_{i t}=\alpha_{i}+b_{i} x_{i t}+c_{1 i} \overline{y_{t}}+c_{2 i} \overline{x_{t}}+e_{i t}
$$

CCE modelinde her bir yatay kesit birimi için, yatay kesit birimi ortalamasını içeren $\mathrm{N}$ sayıda ayrı denklem oluşturulmaktadır. Tahmin edilen $\beta_{\mathrm{i}}{ }^{\prime}$ lere ait denklemler aşağıdaki gibi ifade edilmektedir (Pesaran, 2006:14):

$$
\begin{aligned}
& \hat{b}_{M G}=N^{-1} \sum_{i=1}^{N} \widehat{b}_{\imath} \\
& \hat{b}_{P}=\left(\sum_{i=1}^{N} \theta_{i} X_{i}^{\prime} \bar{M}_{w} X_{i}\right)^{-1} \sum_{i=1}^{N} \theta_{i} X_{i}^{\prime} \bar{M}_{w} y_{i}
\end{aligned}
$$


Tablo 14. Ortak illişkili Etkiler Modeli (CCE-Mean Group $\hat{b}_{M G}$ ) Tahmin Sonuçları Bağımlı Değişken: GDP

\begin{tabular}{cccc}
\hline & Katsayılar & Standart Sapma & \multicolumn{1}{c}{ T-istatistiği } \\
\hline FII & -0.58494 & 0.501024 & -1.16749 \\
\hline
\end{tabular}

Tablo 15. Ortak ilişkili Etkiler Modeli (CCE-Pooled $\hat{b}_{P}$ ) Tahmin Sonuçları

Bağımlı Değişken: GDP

\begin{tabular}{llllll}
\hline & Katsayılar & $\begin{array}{l}\text { Standart } \\
\text { Sapma(NP) }\end{array}$ & T-ist(NP) & $\begin{array}{l}\text { Standart } \\
\text { Sapma(NW) }\end{array}$ & $\begin{array}{l}\text { T- } \\
\text { ist.(NW) }\end{array}$ \\
\hline FII & -0.52968 & 0.210175 & -2.52020 & 0.615444 & -0.8606 \\
\hline
\end{tabular}

Modelde yer alan değişkenler homojen oldukları için CCE Pooled sonuçları dikkate alınmaktadır (Pesaran, 2006:998). Tablo 15'te belirtilen sonuçlar incelendiğinde, finansal istikrarsızlık endeksi (FII) değişkeni önünde yer alan katsayı işaretlerinin teori ile uyumlu olduğu görülmektedir. Elde edilen bulgulara göre, finansal istikrarsızlık \%1 arttı̆ında ekonomik büyüme yaklaşık \%0.53 azalmaktadır. CCE modeli sonucunda tahmin edilen katsayıların anlamlılı̆ı incelendiğinde, \%5 anlamlılık seviyesinde kritik tablo değeri 6.90'dır (Pesaran, 2006:997). CCE Pooled tahmincilerinin standart sapma ve t-ist. değerleri için NW değerleri dikkate alınmakta ve buna göre FII değişkenine ait uzun dönem regresyon katsayısı anlamlıdır.

Tablo 16. Her Bir Yatay Kesit Birimi İçin Hesaplanan Uzun Dönem Katsayıları

\begin{tabular}{lccrc}
\hline \multicolumn{1}{r}{ Ülke } & Fll & Standart Sapma(NW) & Başlangıç & Bitiş \\
\hline Brezilya & -0.731 & 1.157 & 1998 & 2014 \\
Çin & 1.149 & 0.648 & 1998 & 2014 \\
Hindistan & -1.934 & 3.868 & 1998 & 2014 \\
Rusya & -0.436 & 0.849 & 1998 & 2014 \\
Türkiye & -0.973 & 1.189 & 1998 & 2014 \\
\hline
\end{tabular}

Tablo 16'da yer alan sonuçlar incelendiğinde, Çin hariç diğer BRICT ülkeleri için finansal istikrarsızlığın ekonomik büyümeyi olumsuz yönde etkilediği görülmektedir. Finansal istikrarsızlığın ekonomik büyümeyi en çok etkilediği ülke ise Hindistan'dır. Finansal istikrarsızlık artışı nerdeyse kendisinin iki kat kadar ekonomik büyümede azalmaya neden olmaktadır. Her bir ülke için tahmin edilen uzun dönem regresyon katsayılarının anlamlılığı incelendiğinde katsayılara ait t-istatistik değerlerinin (parametre/standart sapma) kritik değerden (6.90) küçük olduğu görülmektedir. Tablo 3.12'de yer alan bulgulara göre, Fll değişkenine ait katsayıların anlamlı olduğu söylenebilmektedir.

\subsection{Nedensellik Iliş̧kisinin Araştırılması}

Panel veri analizi kapsamında temel panel nedensellik testlerinden biri de Dumetriscu ve Hurlin (2012) tarafindan geliştirilen granger nedensellik testi ile benzerlik gösteren panel nedensellik testidir. Granger nedensellik testinde olduğu gibi serilerin durağanlığı söz konusu olduğundan bu test uygulanacağı için serilerin birinci farkları alınarak test uygulanmıştır (Aytun ve Akın:84). Söz konusu test yatay kesit bağımlılığını dikkate almakla birlikte eş-bütünleşme ilişkisinin varlığı ya da yokluğu durumunda uygulanabilmektedir (Dumitrescu ve Hurlin 2012:1450). 
Söz konusu testin diğer bir avantajı ise test küçük örneklemlerde ve yatay kesit bağımlılığı durumlarında güçlü sonuçlar vermesidir. Bu teste ait üç farklı test istatistiği (Whnc, Zhnc, Ztild) hesaplanmaktadır (Dumetriscu ve Hurlin 2012:1453-1455):

$$
\begin{aligned}
& W_{N, T}^{H n c}=\frac{1}{N} \sum_{i=1}^{N} W_{i, T} \\
& Z_{N, T}^{H n c}=\sqrt{\frac{N}{2 K}\left(W_{N, T}^{H n c}-K\right)} \\
& Z_{N, T}^{\text {tild }}=\frac{\sqrt{N}\left[W_{N, T}^{H n c}-N^{-1} \sum_{i=1}^{N} E\left(W_{i, T}\right)\right]}{\sqrt{N^{-1} \sum_{i=1}^{N} \operatorname{var}\left(W_{i, T}\right)}}
\end{aligned}
$$

Yukarıda 21 numaralı denklemde yer alan homojen verilerin varlığında kullanılan Whnc ki kare dağılımı göstermektedir ve $W_{i, T}$ bireysel Wald istatistiklerini ifade etmektedir. 22 ve 23 numaralı denklemde yer alan Zhnc,Ztild standart normal dağılım göstermektedir. Zhnc $\mathrm{N}$ ve T'nin büyük olduğu durumlarda kullanılırken $Z$ tild ise $T>5+2 \mathrm{~K}$ ya da $\mathrm{T} \geq 6+2 \mathrm{~K}$ durumlarında kullanılmaktadır (Dumetriscu ve Hurlin 2012:15431454). Dumetriscu ve Hurlin testine ait hipotezler aşağıdaki gibidir:

\begin{tabular}{|c|c|c|}
\hline Boş Hipotez & T- İstatistik Değeri & Prob. \\
\hline \multicolumn{3}{|c|}{ GDP, FII'nın Granger nedeni değildir } \\
\hline Whnc & 1.7178 & 0.0912 \\
\hline Zhnc & 1.1349 & 0.2095 \\
\hline Ztild & 0.6210 & 0.3289 \\
\hline Boş Hipotez & T- İstatistik Değeri & Prob \\
\hline \multicolumn{3}{|c|}{ FII, GDP'nin Granger nedeni değildir. } \\
\hline Whnc & 2.6749 & 0.0111 \\
\hline Zhnc & 2.6483 & 0.0111 \\
\hline Ztild & 1.7300 & 0.0893 \\
\hline
\end{tabular}

$$
\begin{aligned}
& H_{0}: \beta_{1}=0 \quad \forall i=1, \ldots, N . \\
& H_{1}: \beta_{1} \neq 0 \quad \forall i=1, \ldots, N ; N_{1}+2, \ldots, N .
\end{aligned}
$$

Tablo 17. Panel Nedensellik Testi Sonuçları

Tablo 17'de yer alan sonuçlar değerlendirildiğinde FII'nın GDP'nin granger nedeni olmadığına dair sıfır hipotezi red edilir. Hesaplanan katsayılar $\% 5$ ve $\% 10$ 'da anlamlıdır ve boş hipotez red edilir, kısacası finansal istikrarsızlık ekonomik büyüme arasındaki nedensellik ilişkisi, finansal istikrarsızlıktan ekonomik büyümeye doğrudur.

Panel veri analizi kapsamında tahmin edilen uzun dönem regresyon katsayıları ve nedensellik testi sonuçları bir arada değerlendirildiğinde, elde edilen sonuçların finansal istikrarsızlık ve ekonomik büyüme ilişkisine yer veren yazın ile uyumlu olduğu görülmektedir. Finansal istikrarsızlık ekonomik büyümeyi olumsuz yönde etkilemektedir ve iki değişken arasındaki ilişkinin yönü finansal istikrarsızlıktan ekonomik büyümeye doğrudur. Bu aynı zamanda şu anlama da gelmektedir, çalışmaya yön veren finansal istikrarsızlık arttkça ekonomik büyüme azalmaktadır hipotezi doğrulanmaktadır. 


\section{Sonuç}

iktisat politikaları beklentiler yoluyla finansal piyasalarda katılımcıların piyasa davranışlarını üzerinde önemli bir etkiye sahiptir ve bu nedenle finansal istikrarın gelişimine katkıda bulunmaktadır. Ekonominin farklı zamanlarda, farklı biçimlerde hareket etmesinin nedenlerinden biri de finansal uygulamaların ve finansal yükümlülüklerin yapısının değişmesidir. Günümüzde sıkça rastlanan finansal istikrar kavramı bir amaçtr. Ekonomik faaliyetleri olumsuz yönde etkileyen finansal istikrarsızlık ise bir sorun olup, müdahale edilmediğinde süreç krizle noktalanmaktadır. Finansal istikrarsızlığı arttıran ve ekonomik küreselleşmeye hız kazandıran finansal küreselleşme ile reel getiriler önemini giderek yitirmiş, içgüdüsel tepkinin de etkili olduğu spekülatif kazançlar üretken yatırımlara baskın çıkmıştr. Böyle bir durumdaki istikrarsız finansal sistem artan kırılganlık nedeniyle krizlere yatkın hale gelmektedir ve söz konusu krizler daha sonra uluslararası bir hal kazanarak, ulusal ekonomi politikalarının da denetimini güçleşmektedir. Bu çalışmada özellikle yükselen piyasa ekonomileri kapsamında değerlendirilen BRIC+T ülkeleri ele alınmıştır. Finansal gelişimini tamamlamadan finansal serbestleşme kapsamında hızla dışa açılan yükselen piyasa ekonomileri kırılgan finansal yapıları gereği sıkça krizlerle karşılaşmıştır ve artan finansal istikrarsızlık ekonomik büyümeyi olumsuz yönde etkilemiştir.

Finansal istikrarsızlık ile ekonomik büyüme ilişkisinin test edilmesi amacıyla panel veri analizinden yararlanılan ampirik modelde, BRICT ülkeleri kapsamında finansal istikrarsızlığın ekonomik büyüme üzerindeki etkisi analiz edilmiştir. Ampirik model kapsamında panel veri analizinden yararlanılmıştır. Panel veride zaman ve yatay kesit birimleri birlikte ele alındığı için gözlem sayısı daha fazla olmakta, böylece veriden daha fazla bilgi sağlanabilmektedir. Ayrıca, oluşturulan model daha az kısıtlayıcı varsayım ile tahmin edilebilmekte ve yapılan parametre tahminleri daha güvenilir olmaktadır. Ülkeler arası karşılaştırmaların yapıldığı panel veri analizinden elde edilen sonuçlar daha etkin ve asimptotik olarak tutarlı olmaktadır.

Finansal sistemin karmaşık yapısının gereği dengeden uzak ve durağan olmaması nedeniyle çalışmada durağan olmayan panel veri analizi tercih edilmiştir. Analiz için öncelikle finansal istikrarsızlık endeksi oluşturulmuş, ardından değişkenlere ait eğim katsayılarının homojenliği incelenmiştir. Ayrıca, olası şokların etkilerinin ülkeden ülkeye değişip değişmediğinin araştrııması amacıyla yatay kesit bağımlılığı testinden yararlanılmıştır. Homojen ve yatay kesit bağımlılığı özelliği taşıyan seriler için ikinci nesil panel birim kök testlerinden faydalanılmış, verilerin durağanlığı incelendikten sonra seriler arası eşbütünleşik ilişkinin varlığı ikinci nesil panel eşbütünleşme testleri ile incelenmiştir.

Elde edilen bulgulara göre, finansal istikrarsızlık ekonomik büyümeyi olumsuz bir şekilde etkilemektedir. Artan finansal istikrarsız ekonomik büyümeyi azaltmaktadır. Elde edilen bu sonuç, Loayza ve Ranciere (2006), Enowbi ve Kupukile (2012), Creel vd. (2014), Ahmed vd. (2015) ve Ceballas (2015) ile benzerlik göstermektedir. Ulaşılan sonuç ayrıca etkin piyasa hipotezinin geçerli olmadığını da göstermektedir. Özellike ana akım iktisat teorisinin savunduğu etkin piyasa hipotezinin geçerli olabilmesi için finansal istikrarsızlık ile ekonomik büyüme arasında anlamlı bir ilişkinin bulunmaması gerekirdi. Fakat elde edilen sonuçlar tersine Misnky'nin finansal istikrarsızlık hipotezini desteklemektedir. Finansal piyasalar yapısı gereği istikrarsızdır ve artan finansal istikrarsızlık ekonomik büyümeyi azaltmaktadır. Ekonomik büyümenin azalması ise belli bir süre sonunda ekonomide yaşanacak olası bir daralmayı ya da bir finansal krizi işaret etmektedir.

Diğer çalışmalardan farklı olarak, finansal istikrarsızlık ve ekonomik büyüme arasındaki nedensellik ilişkisinin de incelendiği bu çalışmada, nedensellik ilişkisinin yönü finansal istikrarsızlıktan ekonomik büyümeye doğru olarak bulunmuştur. Böylece, teoriyle uyumlu olarak, artan finansal istikrarsızlığın ekonomik büyümeyi azalttğı ampirik olarak da ortaya konmaktadır. Elde edilen ampirik sonuçlar çalışmanın çıkış noktası olan finansal istikrarsızlığın bir sorun olarak ekonomiye zarar verdiğini, ayrıca yükselen piyasa ekonomileri açısından finansal istikrarsızlığın ekonomik büyümeyi negatif yönde etkilediği hipotezini desteklemekte ve güçlü bir kanıt ortaya sunmaktadır.

Ekonomik büyüme gelişmekte olan ülkelerin karşı karşıya olduğu temel sorunlardan biridir. Ekonomik büyüme, daha yüksek yaşam standartları, sosyal ve insani göstergelerdeki iyileşmelere giden bir yoldur. Finansal istikrarsızı̆̆ı ortadan kaldırmayı amaçlayan reform stratejileri esas olarak büyüme oranlarını yükseltmeyi hedeflemektedir. Koşullara bakılmaksızın tüm ülkeler için aynı büyüme stratejisinin önerilmesi 
gerçekçi olmayacaktır. Özellikle gelişmekte olan ülkeler için yapısal sorunların da dikkate alındığı, finansın ekonomik büyümenin ayrılmaz bir parçası olduğu gözetilerek, yeni büyüme stratejileri geliştirilmeli ve finansal istikrarsızlık kaynaklarına ilişkin çözüm önerileri getirilmelidir. Başarılı politika önerilerinde bulunabilmek için finansal istikrarsızık kaynaklarının da iyi bir şekilde tanımlanması gerekmektedir.

\section{Kaynaklar}

Afonso A., Baxa J., \& Slavík M. (2011). Fiscal developments and financial stress: A threshold VAR analysis. European Central Bank, Working Paper Series 1319.

Ahmed, K., Juliot, M. B. M., \& Abid, I. (2015). Financial development, financial instability and economic growth: Case of maghreb countries. International Journal of Economics and Financial Issues, 5(4), 1043-1054.

Akçay, A. Ö., \& Erataş, F. (2012). Cari açık ve ekonomik büyüme ilişkisinin panel nedensellik analizi ekseninde değerlendirilmesi. http://teacongress.org/papers2012/AKCAY-ERATAS.pdf, 1-26.

Akerlof, G. A. (1970). The market for 'lemons': quality uncertainty and the market mechanism. Quarterly Journal of Economics, 84(3), 488-500.

Akerlof, G. A., \& R. J. Shiller. (2010). Hayvansal güdüler, insan psikolojisi ekonomiyi nasıl yönlendirir ve küresel kapitalizm için niçin önemlidir. İstanbul: Scala Yayıncılık.

Albulescu, C. T. (2010). Forecasting the Romanian financial system stability using a stochastic simulation model. Romanian Journal of Economic Forecasting, 13(1): 81-98.

Albulescu, C. T. (2011). Economic and financial integration of ceecs: The impact of financial instability. AUCO Czech Economic Review, 5, 27-45.

Albulescu, C. T. (2012). Financial stability, monetary policy and budgetary coordination in EMU. Theoretical and Applied Economics, 8(573), 85-96.

Arrow, K. J. (2010). Economic theory and the financial crises, how inefficent incentensive can lead to catastrophes the irrational economist making decisions in a dangerous World. New York: Public Affairs.

Bilgin, C. (2007). Finansal istikrarsızlık sorunu ve iktisat politikası bağlamında Türkiye örneği. Çukurova Üniversitesi Sosyal Bilimler Enstitüsü, Yayımlanmamış Doktora Tezi, Adana.

Breusch, T. S., \& Pagan, A. R. (1980). The lagrange multiplier test and its applications to model specification in econometrics. The Review of Economic Studies, 47(1), 239-253.

Brunnermeier, M., \& Sannikov, Y. (2014). A macroeconomic model with a fnancial sector. American Economic Review, 104, 379-421.

Cardarelli, R., Elekdag, S., \& Lall, S. (2011). Financial stress and economic contractions. Journal of Financial Stability, 7, 78-97.

Ceballos, D., Pascual, M., \& Cantarero, D. (2015). Financial instability and economic environment. http://www.ub.edu/iafi/Membres/DCeballos/bilbao06.pdf, 1-11, (Erişim Tarihi:09.08.2016).

Choi, I. (1993). Improving empirical size of the KPSS test of stationary. http://hompi.sogang.ac.kr/inchoi/workingpaper/in_choi-jetem-_revision_2.pdf, (22.07.2016).

Cihak, M. (2007). Systemic loss: A measure of financial stability. Chez Journal of Economics and Finance, 57(1-2), 5-26.

Creel, J., Hubert, P., \& Labondance, F. (2014). Financial stability and economic performance. Economic Modelling, 48, 25-40.

Çevik El, Diboğlu S. \& Kutan, A. M. (2013). Measuring financial stress in transition economies. Journal of Financial Stability, 9, 597-611.

Davig, T., \& Hakkio C. (2010). What is the effect of financial stress on economic activity?. Federal Econimic Review, (Q II), 35-62, Reserve Bank of Kansas City.

Dumetriscu, E., \& Hurlin C. (2012). Testing for granger non-causality in heterogeneous panels. Economic Modelling, 29(4), 1450-1460.

Eberhardt, M., \& Teal, F. J. (2009). A common factor approach to spatial heterogeneity in agricultural productivity analysis. University Library of Munich, MPRA Paper, 15810: 1-27.

Eggoh, C. J. (2008). Financial development, financial instability and growth: A reappraisal. Law, Economics and Management Faculty, University of Orleans, 1-21. 
Enowbi, M. B., \& Kupukile, M. (2012). Financial instability, financial openness and economic growth in african countries. MPRA, Paper No:43340.

Erarslan, C., \& Timurtaş, M. E. (2015). Avrupa borç krizinin seçilmiş ülke örnekleri üzerindeki etkileri. Gazi iktisat ve işletme Dergisi, 1(2), 17-54.

Erataş, F. (2012). Döviz kuru ve ekonomik büyüme ekseninde Krugman 45 derece kuralının geçerliği: Küresel bir analiz. Dokuz Eylül Üniversitesi, Sosyal Bilimler Enstitüsü, Yayımlanmamış Yüksek Lisans Tezi, İzmir.

Gersl, A., \& Hermanek, J. (2006). Financial stability, indicators: Advantages and disadvantages of their use in the assessment of the financial system stability. Czech National Bank, Financial Stability Report.

Grimaldi M. B. (2010). Etecting and interpreting financial stress in the Euro area. European Central Bank, Working Paper Series 1214.

Güloğlu, B., \& M. İvrendi. (2010). Output fluctuations: Transitory or permanent? The case of Latin America. Applied Economics Letters, 17(4): 381-386.

Hadri, K., \& Kurozumi, E. (2012). A simple panel stationarity test in the presence of serial correlation and a common factor. Economics Letter, 115, 31-34.

Hakkio C. \& W. Keeton. (2009). Financial stress: What is it, how can it be measured and why does it matter?. Federal Reserve Bank of Kansas City - Economic Review, (Q II), 5-50.

Hatzius J., Hooper P., Mishkin F., S., Schoenholtz K., L. \& Watson, M., W. (2010). Financial conditions indexes: A fresh look after the financial crisis. NBER, Working Paper 16150.

Holmfeldt, M., Rydén, A., Strömberg, L., \& Strömqvist, M. (2009). How has the stress on the financial markets developed? An index-based discussion. Riksbank Economic Commentaries, 13, www.riksbank.com/upload/Dokument_riksbank/Kat_publicerat/Ekonomiska\%20kommentarer/2009/ek_kom_ no13_09eng.pdf.

Holló, D., Kremer, M., \& Duca, M. (2012). CISS -Composite indicator of systemic stress in the financial system. European Central Bank, Working Paper 1426.

Hubrich, K., \& Telow, R. J. (2012). Financial stress and economic dynamics the transmission of crises. European Central Bank Working Paper, No:1728.

Illing, M., \& Liu, Y. (2003). An index of financial stress for Canada. National Bank of Canada, Working Papers 14.

Illing, M., \& Liu, Y. (2006). Measuring financial stress in a developed country: An application to Canada. Journal of Financial Stability, 2:243-265.

IMF (International Monetary Found), (2016). IMF annual report 2016, finding solutions together. Financial Stability Report.

IMF, (2017). http://www.imf.org/en/data

Islami, M., \& Kurz-Kim, J. R. (2013). A single composite financial stress indicator and its real impact in the Euro area. Bundesbank, Discussion Paper 31.

Jakubik, P., \& Slacik, T. (2013). Measuring financial (in)stability in emerging Europe: A new index-based approach. Financial Stability Report 25.

Karanovic, G., \& Karanovic, B. (2015). Developing an aggregate index for measuring financial stability in the Balkans. Procedia Economics and Finance, 33(2015), 3-7.

Kemal, A. R. (2001). Debt accumulation and its implications for growth and poverty. The Pakistan Development Review, 40(4), 263-281.

Kliesen, K., L, Owyang, M., T., \& Vermann, E. K. (2012). Disentangling diverse measures: A survey of financial stress indexes. Federal Reserve Bank of St. Louis Econ Review, 2012:369-397.

Kowitt, B. (2009). For Mr. BRIC, Nations Meeting a Milestone, http://archive.fortune.com/2009/06/17/news/economy/goldman_sachs_jim_oneill_interview.fortune/index.h $\mathrm{tm}$, (28.11.2017).

Liu, Z., Waggoner, D. F., \& Zha, T. (2011). Source of macroeconomic fluctuations: A regimeswitching DSGE approach. Quantitative Economics, 2: 251-301.

Loayza, N., \& Ranciere, R. (2006). Financial development, financial fragility and growth. Journal of Money Credit and Banking, 38, 1051-1076.

Minsky, H. P. (1982). The financial instability hypothesis: Capitalist processes and the behavior of the economy. Hyman P. Minsky Archive. Paper 282. http://digitalcommons.bard.edu/hm_archive/282. (19.12.2015). 
Mishkin, F. S. (1998). International capital movements, financial volatility and financial ınstability. NBER, Working Paper 6390, 1-33.

Mishkin, F. S. (1999). Global financial instability: Framework, events, issues. Journal of Economic Perspectives, 13(4), 320.

Mishkin, F. S. (2004). The econonomics of money, banking and financial markets. 7. Baskı, U.S.A: Pearson-Addison Wesley.

Mittnik, S., \& Semmler, W. (2013). The real consequences of financial stress. Journal of Economic Dynamics and Control, 37(8), 1479-1499.

Nelson, W.R., \& Perli, R. (2005). Selected indicators of financial stability. Fourth Joint Central Bank Research Conference, European Central Bank, No:8.

O'Neill, J. (2001). Building better global economic BRICs, http://pro790512df.pic10.websiteonline.cn/upload/buildingbetter-pdf_geEM.pdf, (28.11.2017).

Örmeci, O. (2013). BRIC ülkeleri, http://ydemokrat.blogspot.com.tr/2013/03/bric-ulkeleri.html, (27.11.2017).

Pesaran, H., M. (2004). General diagnostic tests for cross section dependence in panels. Working Paper 0435, University of Cambridge.

Pesaran, H., M. (2006). Estimation and inference in large heterogeneous panels with a multifactor error structure. Econometrica, 74(4), 967- 1012.

Pesaran, H., M. (2007). A simple panel unit root test in the presence of cross-section dependence, Journal of Applied Economics, 22, 265-312.

Pesaran, H., M., \& Tosetti, E. (2011). Large panels with common factors and spatial correlation. Journal of Econometrics, $161,182-202$.

Pesaran, H., M., Ullah, A. \& Yamagata, T. (2008). A bias-adjusted Im test of error crosssection independence. The Econometrics Journal, 11(1), 105-127.

Pesaran, H, M., \& Yamagata, T. (2008). Testing slope homogeneity in large panels. Journal of Econometrics, 142, 50-93.

Pesaran, H. M., \& Yamagata, T. (2012). Testing CAPM with a large number of assets. Discussion Papers 12/05, Department of Economics, University of York.

Pradhan, R. P., Dasgupta, P., \& Samadhan, B. (2013). Finance, development and economic growth in BRICS: A panel data analysis. Journal of Quantitative Economics, 11(6), 308-322.

Rouabah, A. (2007). Mesure de la vulnérabilité du secteur bancaire luxembourgeois. Luxembourg Central Bank, Working Paper24.

Roubini, N., \& Mihm, S. (2011). Crisis economics. New York: Penguin Books.

Roye, B. J. (2014). Financial stress and economic activity in Germany. Emprica, 41, 101-126.

Sinenko, N., Titarenko, D., \& Arins, M. (2013). The Latvian financial stress index as an important element of the financial system stability monitoring framework. Baltic Journal Economics, 13(2), 87-112.

Slingenberg J., W., \& Haan, J. (2011). Forecasting financial stress. De Nederlandsche Bank, Working Paper 292.

Stiglitz, J. E., \& Weiss, A. (1981). Credit rationing in markets with imperfect information, American Economic Review, 71, 393-410.

Sul, D., Phillips, P. C. B., \& Choi, C. Y. (2005). Prewhitening bias in HAC estimation. Oxford Bulletin of Economics and Statistics, 67, 517-546.

Şak, N. (2016). Panel birim kök testleri, Stata ile Panel Veri Modelleri. Selahattin Güriş (Ed.), İstanbul: Der Yayınları.

TCMB, Türkiye Cumhuriyet Merkez Bankası (2016). Finansal istikrar raporu, Sayı:22.

Toda, H. Y., \& Yamamoto, T. (1995). Statistical inference in vector autoregressions with possibly integrated processes. Journal of Econometrics, 66, 225-250.

Ubiliva, D. (2014). On the relationship between financial instability and economic performance: Stressing the business of nonlinear modelling. Agricultural \& Applied Economics Association's, Annual Meeting, 1-24.

Uysal, D. (2011). Mikro iktisadi analiz, Konya: Çizgi Kitapevi.

Ün, T. (2016). Stata ile panel veri analizi, stata ile panel veri modelleri. Selahattin Güriş (Ed.), İstanbul: Der Yayınları.

Vermeulen, R., Hoeberichts, M., Vasicek, B., Zigraiova, D. Smidkova K., \& Haan, J. (2015). Financial stress indices and financial crises. Open Economic Review, 26, 383-406.

Westerlund, J. (2008). Panel cointegration tests of the Fisher effect. Journal of Applied Econometrics, 23(2), $193-233$. 
Finansal İstikrarsızlığın Ekonomik Büyüme Üzerindeki Etkisi: BRICT Ekonomileri

World Bank. (2017). https://data.worldbank.org/data-catalog/global-financial-development.

Yerdelen-Tatoğlu, F. (2012). ileri panel veri analizi, stata uygulamalı. ìstanbul: Beta Yayınları. 